\title{
‡USGS
}

Prepared in cooperation with Horry County Stormwater Management

Relation Between Enterococcus Concentrations and Turbidity in Fresh and Saline Recreational Waters, Coastal Horry County, South Carolina, 2003-04

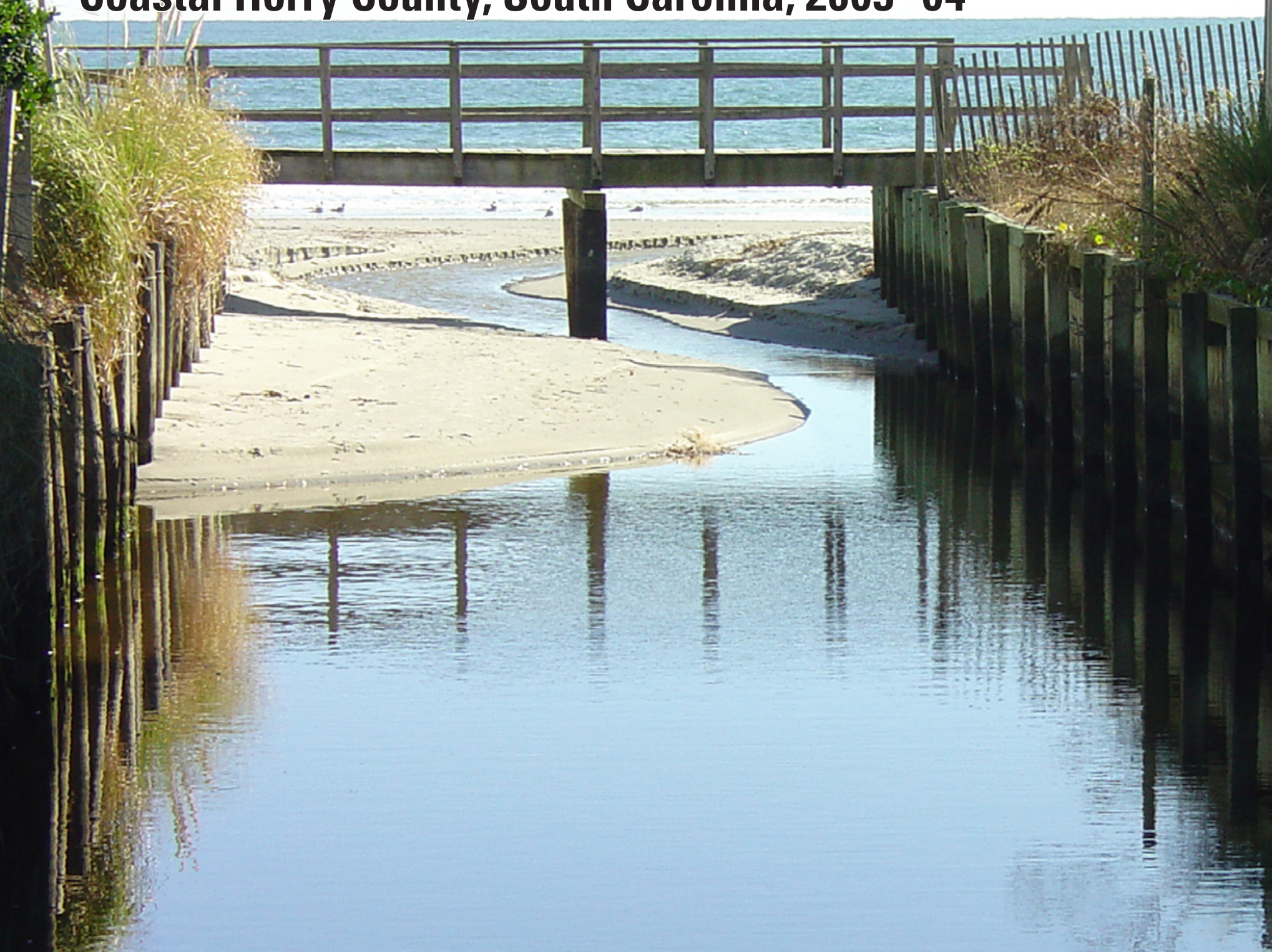

Open-File Report 2016-1015

U.S. Department of the Interior

U.S. Geological Survey 
Cover. Freshwater flows slowly seaward toward the Atlantic 0cean at this location near the 5th Avenue Crosswalk, Surfside Beach, South Carolina. Enterococcus concentrations were compared to continuously measured turbidity at this location by using water-quality data from station 333634078580900 . During 2004, high turbidity was observed during low tide when freshwater from Lake Myrtle flowed seaward and low turbidity was observed during high tide when saline seawater flowed landward. High turbidity was related to the wind-driven resuspension of bed sediments that collect in Lake Myrtle. The bed sediments harbor Enterococci and provide a long-term source of bacteria, even during dry periods.

(Photograph by J.E. Landmeyer). 


\section{Relation Between Enterococcus \\ Concentrations and Turbidity in \\ Fresh and Saline Recreational \\ Waters, Coastal Horry County, \\ South Carolina, 2003-04}

By James E. Landmeyer and Thomas J. Garigen

Prepared in cooperation with Horry County Stormwater Management

Open File Report 2016-1015 


\title{
U.S. Department of the Interior SALLY JEWELL, Secretary
}

\section{U.S. Geological Survey Suzette M. Kimball, Director}

\author{
U.S. Geological Survey, Reston, Virginia: 2016
}

For more information on the USGS - the Federal source for science about the Earth, its natural and living resources, natural hazards, and the environment—visit http://www.usgs.gov or call 1-888-ASK-USGS.

For an overview of USGS information products, including maps, imagery, and publications, visit http://store.usgs.gov.

Any use of trade, firm, or product names is for descriptive purposes only and does not imply endorsement by the U.S. Government.

Although this information product, for the most part, is in the public domain, it also may contain copyrighted materials as noted in the text. Permission to reproduce copyrighted items must be secured from the copyright owner.

Suggested citation:

Landmeyer, J.E., and Garigen, T.J., 2016, Relation between Enterococcus concentrations and turbidity in fresh and saline recreational waters, coastal Horry County, South Carolina, 2003-04: U.S. Geological Survey Open-File Report 2016-1015, 21 p., http://dx.doi.org/10.3133/ofr20161015.

ISSN 2331-1258 (online 


\section{Contents}

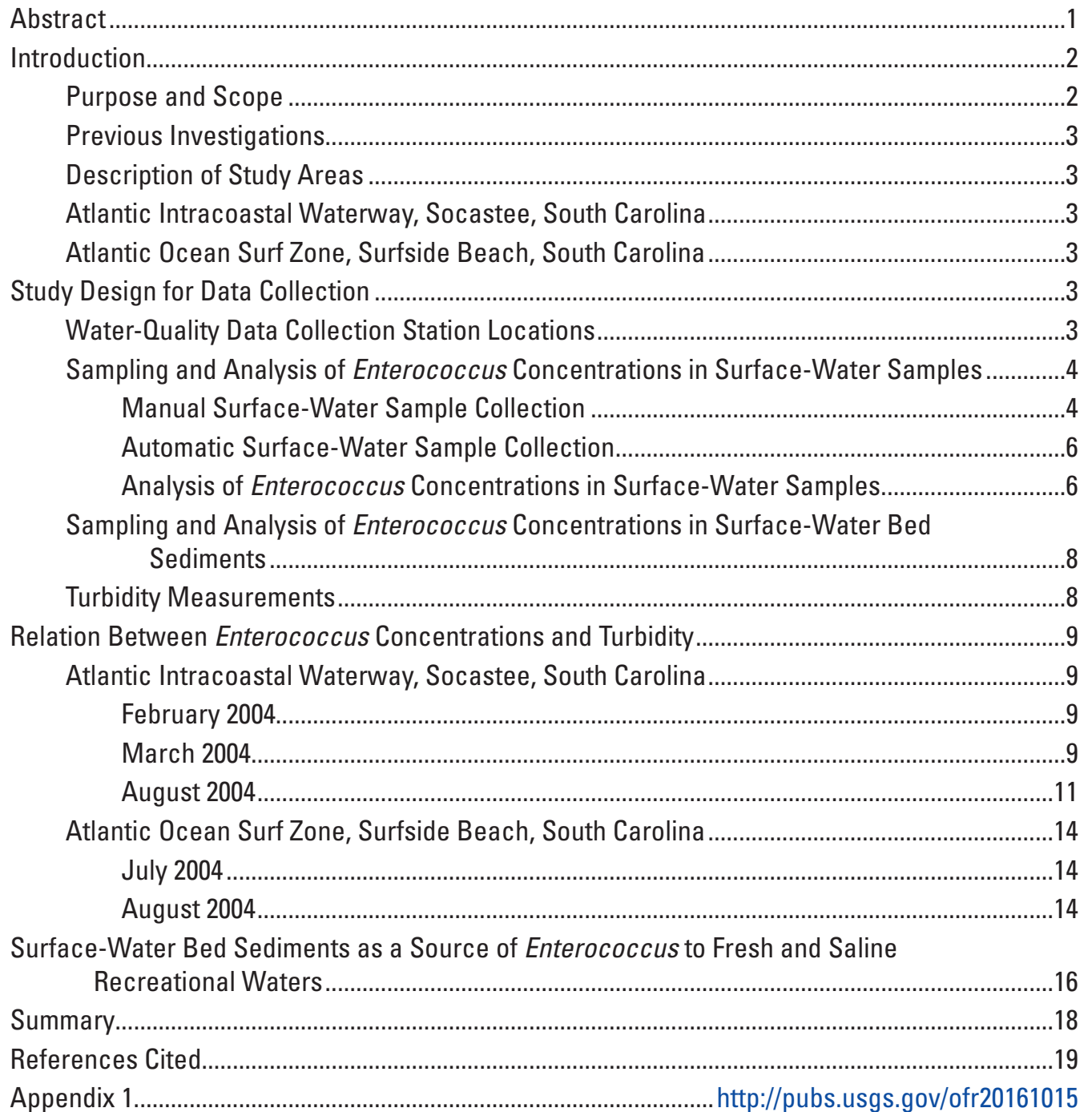

\section{Figures}

1. Map showing location of geophysical provinces, Horry County, and Socastee

2. Aerial photograph of the drainage area delineation of an unnamed tributary to the Atlantic Intracoastal Waterway, Socastee, South Carolina

3. Aerial photograph of the drainage area delineation of two adjacent basins that drain through Dogwood Lake and Lake Myrtle, respectively, to the surf zone of the Atlantic Ocean near Surfside Beach, South Carolina

4. Aerial photograph of the Highway 707 Bridge water-quality data collection station and bed-sediment location near Socastee, South Carolina

5. Aerial photograph of the 11th Avenue crosswalk water-quality data collection station and bed-sediment locations near Surfside Beach, South Carolina. 
6. Aerial photograph of the 5 th Avenue crosswalk water-quality data collection station and bed-sediment locations near Surfside Beach, South Carolina..

7. Photograph of the method used to manually collect surface-water samples by placing a 500-millileter high-density polyethylene bottle in a metal bucket attached to the end of a telescoping pole

8. Photograph of the method used to automatically collect surface-water samples by using an automatic water sampler

9. Photograph of the multiparameter sonde being installed in the polyvinyl chloride pipe open to the surface-water column, 11th Avenue crosswalk water-quality data collection station near Surfside Beach, South Carolina. . .8

10. Photograph of the water-quality data collection station installed at the 5th Avenue crosswalk near Surfside Beach, South Carolina . .8

11. Photograph of the water-quality data collection station installed at the 11th Avenue crosswalk near Surfside Beach, South Carolina .8

12. Photograph of the water-quality data collection station installed at Highway 707 Bridge near Socastee, South Carolina.

13. Graph showing Enterococcus concentration in surface-water samples collected using manual and automatic water-sample collection approaches, precipitation, and turbidity, February 19-20, 2004, Highway 707 Bridge water-quality data collection station near Socastee, South Carolina.

14. Graph showing Enterococcus concentration in surface-water samples collected using the automatic sampler compared to turbidity measurements, February 19-20, 2004, Highway 707 Bridge water-quality data collection station near Socastee, South Carolina.

15. Graph showing Enterococcus concentration in surface-water samples collected using an automatic sampler, precipitation, and turbidity before, during, and after a precipitation event, March 8-10, 2004, Highway 707 Bridge water-quality data collection station near Socastee, South Carolina.

16. Graph showing Enterococcus concentration in surface-water samples collected automatically compared to turbidity measurements, March 8-10, 2004, Highway 707 Bridge water-quality data collection station near Socastee, South Carolina......

17. Graph of Enterococcus concentration in surface-water samples collected automatically compared to precipitation, March 8-10, 2004, Highway 707 Bridge water-quality data collection station near Socastee, South Carolina.

18. Graph showing Enterococcus concentration in surface-water samples collected using manual and automatic water-sample collection approaches, precipitation, and turbidity, August 12-18, 2004, Highway 707 Bridge water-quality data collection station near Socastee, South Carolina.

19. Graph showing Enterococcus concentration in water samples collected using the automatic sample collector compared to turbidity, August 2004, Highway 707 Bridge water-quality data collection station near Socastee, South Carolina.

20. Graph showing Enterococcus concentration in surface-water samples collected using manual and automatic water-sample collection methods, precipitation, and turbidity, July 15-19, 2004, 5th Avenue crosswalk water-quality data collection station near Surfside Beach, South Carolina.

21. Graph showing Enterococcus concentration in surface-water samples compared to turbidity, July 2004, 5th Avenue crosswalk water-quality data collection station near Surfside Beach, South Carolina

22. Graph showing Enterococcus concentration collected using the automatic sample collector compared to precipitation and turbidity, August 2004, 5th Avenue crosswalk water-quality data collection station near Surfside Beach, South Carolina. 
23. Graph showing Enterococcus concentration in surface-water samples compared to turbidity, August 2004, 5th Avenue Crosswalk water-quality data collection station near Surfside Beach, South Carolina

24. Graph of turbidity and specific conductance concentration, August 12-18, 2004, 5th Avenue crosswalk water-quality data collection station near Surfside Beach, South Carolina......

25. Graph of Enterococcus concentration measured in bed-sediment samples collected from the three water-quality data collection stations and incubated over time in static microcosms in the laboratory

\section{Table}

1. Water-quality data collection stations, Horry County, South Carolina ...

\section{Appendix tables}

[Excel file available for download at http://pubs.usgs.gov/ofr20161015]

1-1 Enterococcus concentrations, relative percent differences, turbidity, and precipitation data collected at the Highway 707 Bridge Water-Quality Data Collection Station near Socastee, SC, 2004.

1-2 Enterococcus concentrations, turbidity, and precipitation data collected at the 5th Avenue crosswalk Water-Quality Data Collection Station near Surfside Beach, SC, 2004.

1-3. Enterococcus concentrations in surface-water bed sediments collected in coastal Horry County, 2004. 


\section{Conversion Factors}

Inch/Pound to International System of Units

\begin{tabular}{lcll}
\hline & Multiply & By & \multicolumn{1}{c}{ To obtain } \\
\hline & \multicolumn{2}{c}{ Length } \\
\hline inch (in.) & 2.54 & centimeter (cm) \\
inch (in.) & 25.4 & millimeter (mm) \\
foot (ft) & 0.3048 & meter (m) \\
\hline
\end{tabular}

International System of Units to Inch/Pound

\begin{tabular}{lcc}
\hline \multicolumn{1}{c}{ Multiply } & By & To obtain \\
\hline & Length & \\
\hline micrometer $(\mu \mathrm{m})$ & 0.00003937 & inch (in.) \\
\hline milliliter $(\mathrm{mL})$ & Volume & \\
\hline & 0.03382 & ounce, fluid (fl. oz) \\
\hline gram $(\mathrm{g})$ & \multicolumn{2}{c}{ Mass } \\
\hline
\end{tabular}

Temperature in degrees Celsius $\left({ }^{\circ} \mathrm{C}\right)$ may be converted to degrees Fahrenheit $\left({ }^{\circ} \mathrm{F}\right)$ as follows:

${ }^{\circ} \mathrm{F}=\left(1.8 \mathrm{x}^{\circ} \mathrm{C}\right)+32$

Temperature in degrees Fahrenheit $\left({ }^{\circ} \mathrm{F}\right)$ may be converted to degrees Celsius $\left({ }^{\circ} \mathrm{C}\right)$ as follows:

${ }^{\circ} \mathrm{C}=\left({ }^{\circ} \mathrm{F}-32\right) / 1.8$

\section{Datums}

Horizontal coordinate information is referenced to the North American Datum of 1927 (NAD 27) or North American Datum 1983 (NAD 83) where indicated.

\section{Supplemental Information}

Specific conductance is given in microsiemens per centimeter at 25 degrees Celsius $(\mu \mathrm{s} / \mathrm{cm}$ at $\left.25^{\circ} \mathrm{C}\right)$.

Concentrations of chemical constituents in water are given in either milligrams per liter ( $\mathrm{mg} / \mathrm{L}$ ) or micrograms per liter $(\mu \mathrm{g} / \mathrm{L})$.

Oxidation-reduction potential is given in millivolts $(\mathrm{mV})$. 


\section{Abbreviations}

$\begin{array}{ll}\text { E. coli } & \text { Escherichia coli } \\ \text { EPA } & \text { U.S. Environmental Protection Agency } \\ \text { FIB } & \text { fecal indicator bacteria } \\ \text { FNU } & \text { formazin nephelometric units } \\ \text { HUC } & \text { hydrologic unit code } \\ \text { MPN } & \text { most probable number } \\ \text { NWIS } & \text { National Water Information System } \\ \text { USGS } & \text { U.S. Geological Survey } \\ \text { WODCS } & \text { water-quality data collection station }\end{array}$




\section{Acknowledgments}

Technical assistance in the initial phases of the study during the summer of 2003 from personnel with Davis \& Floyd, Inc., in particular Carl Burrell, is appreciated. Discussions with Fred Earnhardt, South Carolina Department of Health and Environmental Control, early in the project were useful in designing the scope of work. The level of interest and positive feedback from the permanent residents and tourists of the area near the sites was refreshing, motivating, and greatly appreciated. The project was supported by the South Carolina Department of Environmental Control 319 Grant Program, and the U.S. Environmental Protection Agency.

Data collection by Henry T. Herlong, U.S. Geological Survey (retired), and U.S. Geological Survey Volunteer for Science, Lisa Stephenson (deceased), was greatly appreciated during sampling in 2004. Support for the project was provided by the U.S. Geological Survey Cooperative Water Program. 


\title{
Relation Between Enterococcus Concentrations and Turbidity in Fresh and Saline Recreational Waters, Coastal Horry County, South Carolina, 2003-04
}

\author{
By James E. Landmeyer ${ }^{1}$ and Thomas J. Garigen ${ }^{2}$
}

\section{Abstract}

Bacteria related to the intestinal tract of humans and other warm-blooded animals have been detected in fresh and saline surface waters used for recreational purposes in coastal areas of Horry County, South Carolina, since the early 2000s. Specifically, concentrations of the facultative anaerobic organism, Enterococcus, have been observed to exceed the single-sample regulatory limit of 104 colony forming units per 100 milliliters of water. Water bodies characterized by these concentrations are identified on the 303(d) list for impaired water in South Carolina; moreover, because current analytical methods used to monitor Enterococcus concentrations take up to 1 day for results to become available, water-quality advisories are not reflective of the actual health risk.

To determine if Enterococcus concentrations in surface water could be assessed in a more rapid manner, an investigation was completed between 2003 and 2004 in the study area of coastal Horry County, South Carolina. The study was designed to assess the relation between Enterococcus concentrations and turbidity, which, unlike Enterococcus concentrations, can be measured continuously by using a multiparameter water-quality sensor and results reported in real time. In 2003, three water-quality data collection stations that included a multiparameter water-quality sensor that measured turbidity were located in three representative surface-water basins in coastal Horry County, South Carolina. All these locations had previous reports of high Enterococcus concentrations. At each station, the water-quality sensor was placed in the water column and continuously measured turbidity, $\mathrm{pH}$, specific conductivity, dissolved oxygen, and temperature. Each water-quality data collection station also monitored instantaneous precipitation and wind speed and direction. Surface-water samples were collected at each station during events characterized by no precipitation and by some recorded precipitation using manual and automatic methods, and analyzed for Enterococcus concentrations. A comparison of Enterococcus concentrations in surface-water samples collected simultaneously using both methods indicated a positive relation, although the average percent relative difference between the methods was 46 percent.

During a period of no precipitation in February 2004, no relation between turbidity and Enterococcus concentrations was observed for surface-water samples collected at the water-quality data collection station located in the channel that drains a freshwater swamp. In contrast, during periods of precipitation in March and August 2004 at this location, a positive relation was observed between turbidity and Enterococcus concentrations in surface-water samples; that is, water samples characterized by higher turbidity also contained higher Enterococcus concentrations. At the water-quality data collection station located in a channel that drains to the surf zone of the Atlantic Ocean, no relation was observed between turbidity and Enterococcus concentrations during periods of either no precipitation (July 2004) or precipitation (August 2004). At this location, the turbidity was inversely related to relative tide height, high turbidity was observed during low tide when freshwater flowed seaward, and low turbidity was observed during high tide when saline seawater flowed landward.

The positive relation observed between turbidity and Enterococcus concentrations in surface water at the waterquality data collection station located in the channel that drains a freshwater swamp may be attributed to bacterial survival in the abundant channel bed sediments that characterized this more naturalized area. Surface-water bed sediments collected near each water-quality data collection station and the surf zone were incubated in static microcosms in the laboratory and analyzed for Enterococcus concentrations over time. Enterococcus concentrations continued to persist in bed sediments collected in the channel that drains the swamp even after almost 4 months of incubation. Conversely, enterococci were not observed to persist in bed sediments characterized by high specific conductance. Although it is currently (2016) unknown whether this persistence of enterococci demonstrates growth or viability, the data indicate that enterococci can exist in channel bed-sediment environments outside of a host

\footnotetext{
${ }^{1}$ U.S. Geological Survey

${ }^{2}$ Horry County Stormwater Management
} 
Relation Between Enterococcus Concentrations and Turbidity in Fresh and Saline Recreational Waters

for a long time. This observation confirms previous reports that challenge the use of Enterococcus concentrations as an indicator of the recent introduction of fecal-related material and the associated acute risk to other pathogens.

\section{Introduction}

Pathogenic organisms present in the aquatic environment often pose a threat to human health. These organisms use water as a vector to infect hosts. The ability to detect the presence of some pathogens in water, such as those that cause cholera or typhoid, is analytically extensive; therefore, more readily detectable microorganisms that are related to the presence of pathogens are used as surrogates. The surrogates, which have similar survival times once introduced to the aquatic environment, also are in waste material that has a high probability of having pathogens; for example, coliform bacteria have been used as surrogates for pathogens for some time (Dufour, 1984; U.S. Environmental Protection Agency, 1986; American Public Health Association, 1992; U.S. Environmental Protection Agency, 2012). Coliform bacteria are gram-negative, facultatively anaerobic, rod-shaped bacteria that can live in oxic and anoxic conditions. Because coliform bacteria are widespread in the environment and are associated with nonwaste sources, a subset of coliform, the fecal coliform bacteria, are used as a pathogen indicator. The familiar fecal coliform, Escherichia coli (E. coli), makes up a large percentage of human waste. Fecal streptococci also are fecal bacteria that inhabit the enteric system of warm-blooded animals. A subgroup of these microorganisms used as surrogates for feces are the Enterococcus spp. (enterococci), such as Enterococcus faecalis, Enterococcus faecumi, Enterococcus gallinarum, and Enterococcus avium. These bacteria are capable of growth in more saline surface-water environments and are often the indicator of choice for monitoring the water quality of saline coastal waters. The Enterococcus concentration is currently the preferred indicator of possible fecal contamination for recreational water on account of the strong correlation between Enterococcus concentrations and swimming-associated gastroenteritis (Cabelli, 1977; Cabelli and others, 1982; Cabelli, 1983).

High levels of fecal-associated bacteria have been and continue to be measured in the surf zone of the eastern coastline of the United States, which resulted in an increase in the number of beach closings (Natural Resources Defense Council, 2002, 2014) and attendant coverage by news media. In South Carolina, fecal-associated bacteria, particularly enterococci, have been detected above Federal- and Statemandated permissible levels in some coastal waters used for recreational purposes near the popular, tourist area of Myrtle Beach and the adjacent Atlantic Intracoastal Waterway. The source of the fecal bacteria being detected in the surface-water bodies in Horry County, South Carolina, remains largely unknown at this time (2016), although some data indicate that the enterococci may originate from nonpoint human and (or) animal (particularly bird) sources (Davis \& Floyd, Inc., 2002).
Regardless of the exact source(s) of the elevated Enterococcus concentrations, the analytical methods currently (2016) required by officials to determine the degree of associated risk exposure takes from 1 to 2 days to analyze following collection of the water sample; hence, any risk assessment decisions are made after the original risk had gone unnoticed (and unannounced). As such, there is a continued need for an approach that could be used to indicate the presence (or absence) of high levels of fecal indicator bacteria (FIB) as rapidly as possible that would enable proactive decisions to be made regarding beach closures before bacteria reach harmful levels. Such an approach could be used to subsequently lift these closures when conditions that resulted in higher bacteria levels return to normal; moreover, this approach could be used to audit beach closures based on infrequent sampling or generalized relations between precipitation amounts and bacteria levels that may be too restrictive or not sufficiently protective.

The research approach evaluated as part of this investigation is based on the casual relation first observed between high levels of FIB, high surface-water flows, and high turbidity as part of a study of bacterial sources in Withers Swash, Horry County, S.C., conducted by the U.S. Geological Survey (USGS), in cooperation with the City of Myrtle Beach, S.C., between 1991 and 1993 (Guimaraes, 1995). Considering that most fecal bacteria are not free-floating organisms and can attach to solid surfaces, it is not surprising that more than 90 percent of fecal bacteria are associated with sediment particles between 0.45 and 10 micrometers $(\mu \mathrm{m})$ (Schillinger and Gannon, 1982; Auer and Niehaus, 1993). As such, these initial observations indicate that turbidity, a physical property of water that can be measured continuously, could provide a surrogate for bacteria levels in the surface-water column.

\section{Purpose and Scope}

The purpose of this report is to present the results of an investigation of the relation between Enterococcus concentrations and turbidity in fresh and saline coastal recreational surface waters in the unincorporated areas of coastal Horry County, S.C. Three water-quality data collection stations (WQDCSs) were installed in 2003 in the study area to monitor the turbidity of surface water in one basin that drains to the Atlantic Intracoastal Waterway and in two basins that are adjacent to each other and drain to the surf zone of the Atlantic Ocean. The WQDCSs were operated until the end of 2004.

At each WQDCS, surface-water samples were collected using manual and automatic sample-collection methods, and water samples were analyzed in the laboratory for Enterococcus concentrations. The relation between turbidity and Enterococcus concentrations was examined in 2004 during multiple events characterized from the absence of precipitation to significant precipitation. Finally, the extent that enterococci could survive in surface-water bed sediments collected in the study area was evaluated in the laboratory using static microcosms. The work was made possible as part of a U.S. Environmental Protection Agency (EPA) 319 Grant to Horry County Stormwater Management and the Federal-State Cooperative Water Program of the USGS. 


\section{Previous Investigations}

The USGS has played a primary role in the evaluation of the relation between the physical properties and chemical composition of surface water and levels of FIB, E. coli, and Enterococcus concentrations at multiple locations in the United States. The studies that have examined surrogates for FIB include those conducted in Kansas (Christensen and others, 2000; Christensen, 2001) and Virginia (Hyer and Moyer, 2003). The studies that have examined surrogates for E. coli include those conducted in Ohio (Francy and others, 2002; Brady and others, 2009), Kansas (Rasmussen and others, 2005; Rasmussen and others, 2008; Rasmussen and Gatotho, 2014), Pennsylvania (Zimmerman, 2006), Michigan (Holtschlag and others, 2008), Nebraska (Schaepe and others, 2014), and the Great Lakes area (Francy and others, 2013). The studies that have examined surrogates for FIB and $E$. coli collected at the same time include those conducted in Kansas (Rasmussen and Zeigler, 2003) and Wisconsin (Baldwin and others, 2013). The studies that have examined surrogates for E. coli and Enterococcus concentrations measured at the same time include those conducted in Michigan (Haack and others, 2003) and Wisconsin (Juckem and others, 2012). The studies that have evaluated surrogates for fecal coliform, E. coli, and Enterococcus concentrations measured at the same time include those conducted in Pennsylvania (Fulton and Buckwalter, 2004; Buckwalter and others, 2006).

These previous investigations were conducted in study areas that are characterized by freshwater surface-water systems. The investigation described in this report is, to the authors' knowledge, the first study that examines the relation between continuously measured turbidity and Enterococcus concentrations in recreational surface waters characterized by saline conditions. This investigation builds on previous reconnaissance work done in Horry County, S.C. (Davis \& Floyd, Inc., 2002), in which enterococci were detected in all the surface-water channels that discharged to the surf zone of the Atlantic Ocean.

\section{Description of Study Areas}

Horry County, S.C., is located in the Lower Coastal Plain Physiographic Province of South Carolina (fig. 1). Three basins that represent drainage systems in coastal Horry County, S.C., were examined and are described below.

\section{Atlantic Intracoastal Waterway, Socastee, South Carolina}

This basin drains to the Atlantic Intracoastal Waterway near Socastee, S.C. (fig. 2). The 12-digit hydrologic unit code (HUC) (Eidson and others, 2005) for this basin is 030402060906. Surface-water drainage flows through established residential areas, wetlands, swamps, and riparian vegetation all draining to an unnamed tributary to the Atlantic Intracoastal Waterway.
The tributary is partly channelized near overpassing roads, but retains its natural, meandering channel across most of the basin. The bed load is comprised of sands, silts, and clays.

\section{Atlantic Ocean Surf Zone, Surfside Beach, South Carolina}

The two basins examined near Surfside Beach, S.C., are located adjacent to each other and drain to the surf zone of the Atlantic Ocean (fig. 3). The 12-digit HUC for these basins is 030402080307 . Drainage in the northernmost basin is conveyed through a highly developed, residential area to Dogwood Lake, an artificial freshwater lake designed to control flooding. Surface water in the second basin flows into Lake Myrtle, and then to the surf zone through a channel. During periods of high tide, salt water from the surf zone of the Atlantic Ocean can flow up both channels. Surface water from Dogwood Lake also can flow westward through a ditch to Lake Myrtle.

\section{Study Design for Data Collection}

The general design of the study was to examine the relation between Enterococcus concentrations measured in surface-water samples to concurrent measurements of turbidity measured using a continuous, turbidity sensor. Surfacewater samples were collected in the field using manual and automatic sample-collection methods, and Enterococcus concentrations were determined in the laboratory to evaluate the degree of relation between Enterococcus concentrations and turbidity in surface-water bodies used for recreational purposes in coastal Horry County, S.C. The data were examined using exploratory data analysis, which is based on using visual methods to discover the main characteristics of the dataset (Tukey, 1977). The limited number of samples that could be collected during the study, and the wide range of precipitation amounts that characterized the study period, precluded the development of site-specific regression equations of the relation between turbidity and Enterococcus concentrations; moreover, this investigation used a laboratory approach with static microcosms to evaluate the survival of enterococci in surface-water bed sediments collected in freshand surface-water bodies in the study area.

\section{Water-Quality Data Collection Station Locations}

Three WQDCSs were installed in the three basins at the beginning of the study (table 1). The first WQDCS is in the unnamed tributary that drains to the Atlantic Intracoastal Waterway near the Highway 707 Bridge (fig. 4). The second WQDCS is located at a crosswalk at 11th Avenue near Surfside Beach (fig. 5). The third WQDCS is located at a crosswalk at 5th Avenue near Surfside Beach (fig. 6). The WQDCSs were discontinued after the study ended in December 2004. 


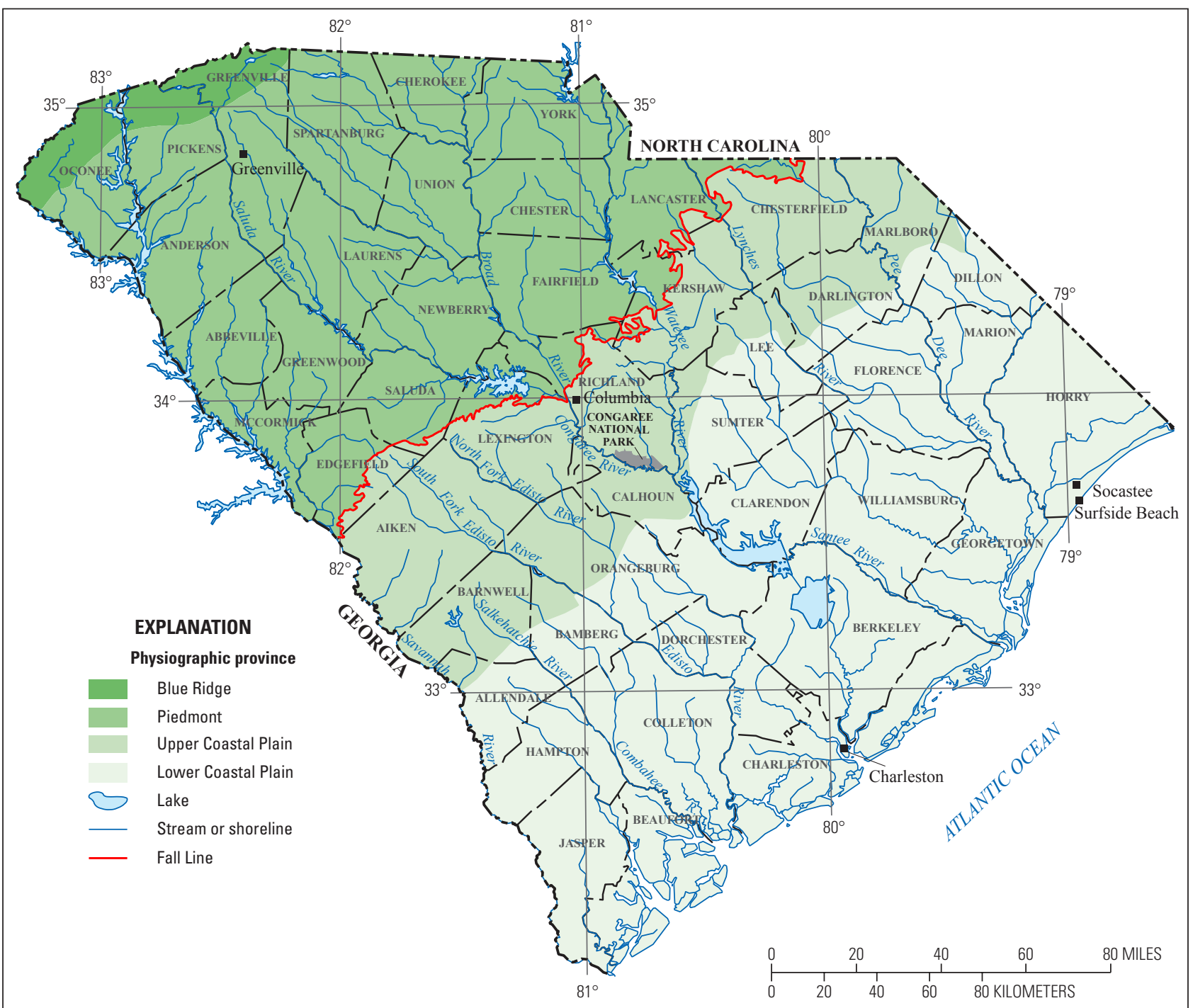

Base from U.S. Geological Survey digital data, 2001 and 2002,

1:2,000,000-scale Albers Equal Area Conic projection,

standard parallels $29^{\circ} 30^{\prime} \mathrm{N}$ and $45^{\circ} 30^{\prime} \mathrm{N}$, central

meridian $96^{\circ} 00^{\prime} \mathrm{W}$, rotated $-8.5^{\circ}$, datum NAD 27

Figure 1. Geophysical provinces, Horry County, and Socastee and Surfside Beach, South Carolina.

\section{Sampling and Analysis of Enterococcus Concentrations in Surface-Water Samples}

Surface-water samples were collected from surface water at the three WQDCSs during multiple low-flow and high-flow events in 2004. The surface-water samples were collected using manual and automatic sampling methods.

\section{Manual Surface-Water Sample Collection}

Surface-water samples were collected using manual sampling methods during 2004 and represent background conditions (no precipitation) and event-driven conditions (measurable precipitation). Manual surface-water samples were collected by placing a 500-milliliter (mL) high-density polyethylene bottle in a metal bucket attached to the end of a telescoping pole (fig. 7). Before use, each bottle was sterilized with alcohol, capped, and wrapped in aluminum foil. The sample bottle was lowered into the surface water near each multiparameter sensor. This method enabled the water sample to be collected with minimal disturbance to the stream-bed sediment (that would have occurred if samples were collected by wading into the surface water); therefore, the data can be comparable to turbidity values reported by the instream sensor. All sample bottles were immediately capped upon collection and placed on ice in a cooler for transport to the USGS water-quality laboratory in Columbia, S.C. Because of the distance between the WQDCSs and the laboratory and the fact that the samples were collected for research rather than compliance purposes, some samples were processed between 24 and 48 hours of collection. 


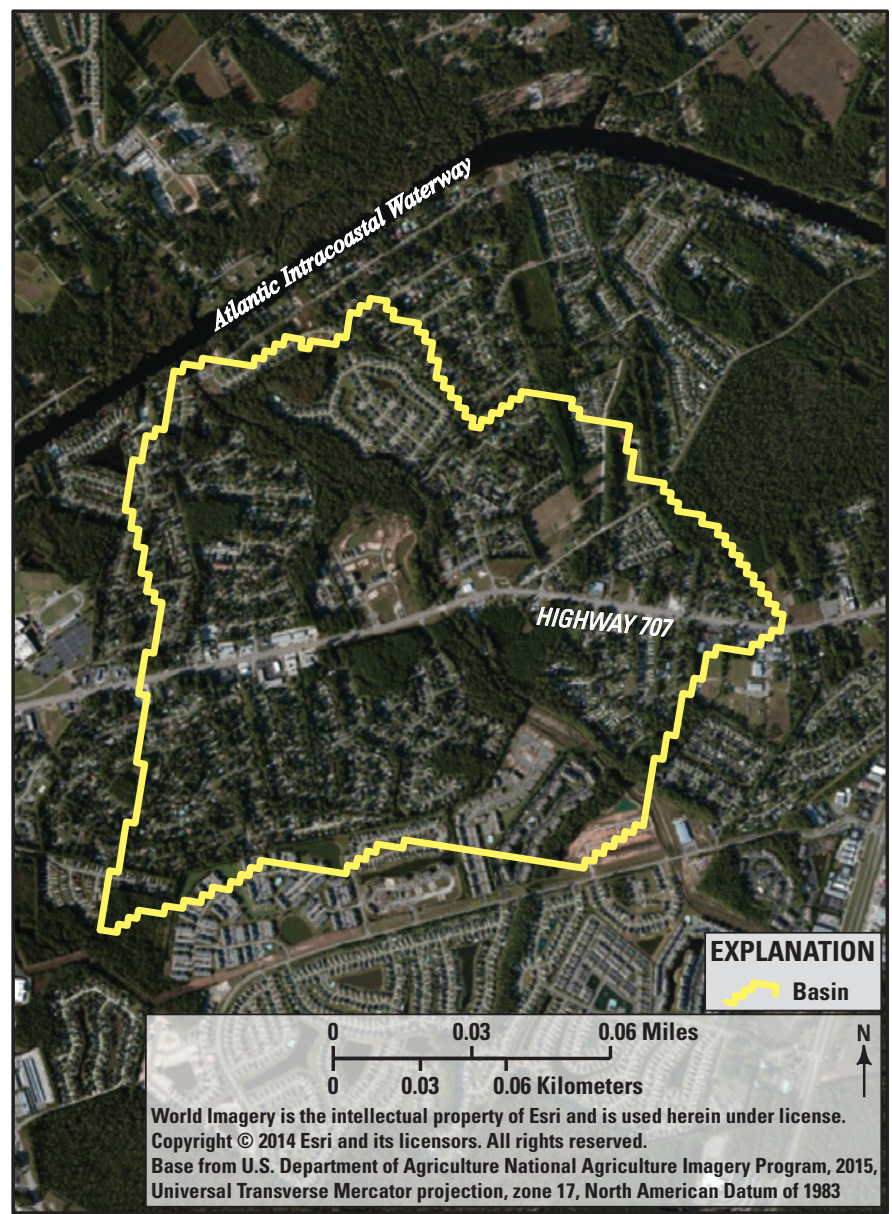

Figure 2. Drainage area delineation of an unnamed tributary to the Atlantic Intracoastal Waterway, Socastee, South Carolina. The 12-digit hydrologic unit code for this basin is 030402060906 .

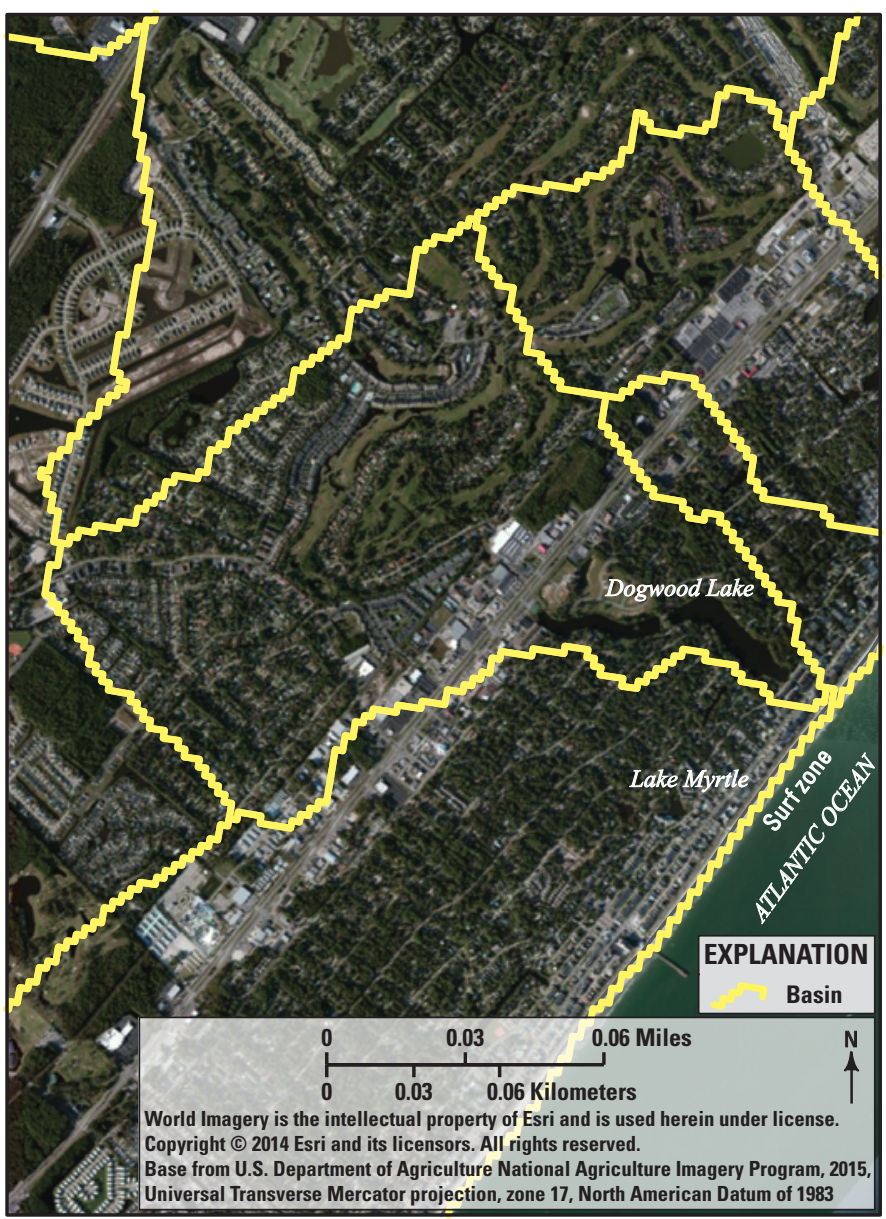

Figure 3. Drainage area delineation of two adjacent basins that drain through Dogwood Lake and Lake Myrtle, respectively, to the surf zone of the Atlantic Ocean near Surfside Beach, South Carolina. The 12-digit hydrologic unit code for these basins is 030402080307.

Table 1. Water-quality data collection stations, Horry County, South Carolina.

[NWIS, National Water Information System; HUC, Hydrologic Unit Code; AIW, Atlantic Intracoastal Waterway; dd mm ss.ss, degrees, minutes, seconds]

\begin{tabular}{|c|c|c|c|c|c|}
\hline $\begin{array}{l}\text { NWIS station } \\
\text { number }\end{array}$ & Station name & Basin description & $\begin{array}{l}\text { Latitude } \\
\text { (dd mm ss.ss) }\end{array}$ & $\begin{array}{l}\text { Longitude } \\
\text { (dd mm ss.ss) }\end{array}$ & 12-digit HUC \\
\hline 334108078585300 & Highway 707 Bridge & $\begin{array}{l}\text { Unnamed tributary to the AIW near } \\
\text { Socastee, South Carolina }\end{array}$ & $33^{\circ} 41^{\prime} 08.55^{\prime \prime}$ & $78^{\circ} 58^{\prime} 52.60^{\prime \prime}$ & 030402060906 \\
\hline 333649078575500 & 11th Avenue Crosswalk & $\begin{array}{l}\text { Dogwood Lake near Surfside Beach, } \\
\text { South Carolina }\end{array}$ & $33^{\circ} 36^{\prime} 48.38^{\prime \prime}$ & $78^{\circ} 57^{\prime} 55.01 "$ & 030402080307 \\
\hline
\end{tabular}




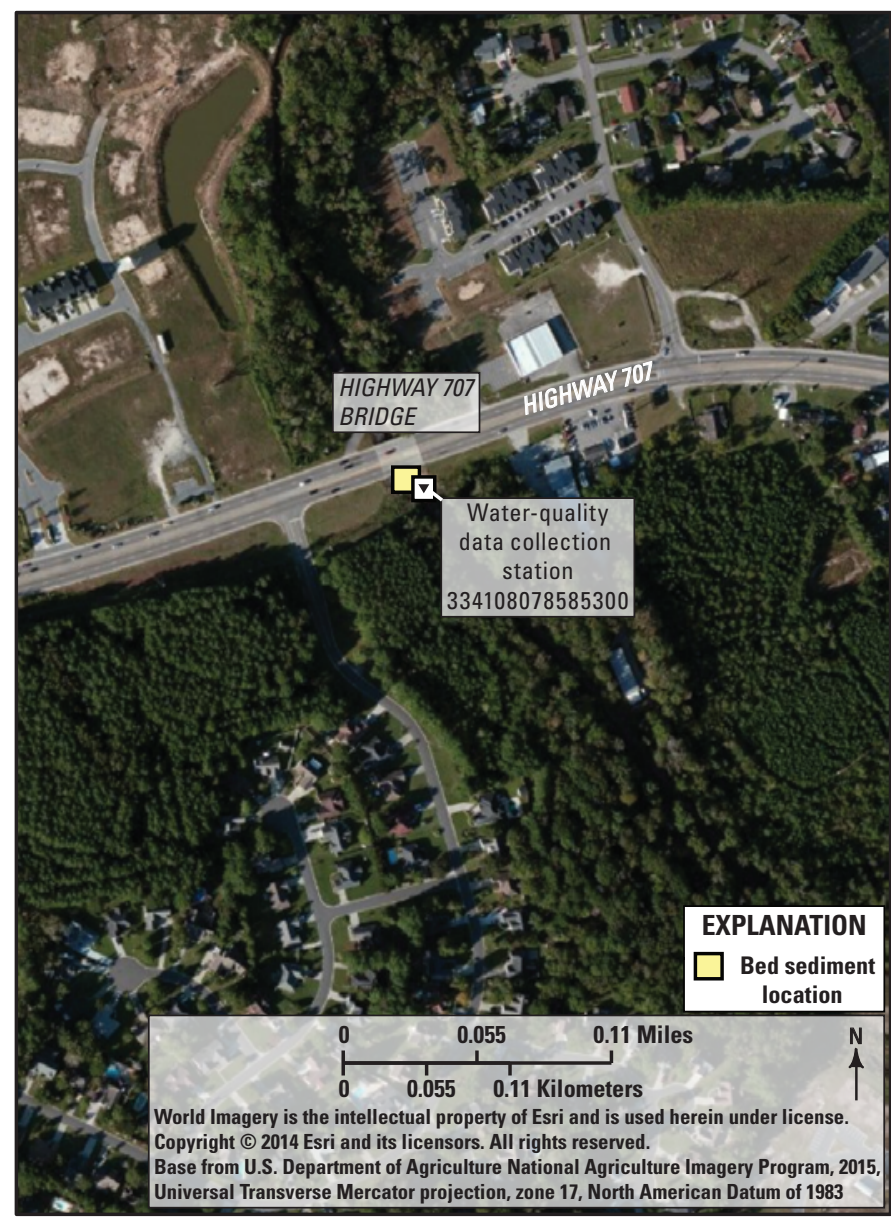

Figure 4. The Highway 707 Bridge water-quality data collection station and bed-sediment location near Socastee, South Carolina. The 12-digit hydrologic unit code for this basin is 030402060906 and is depicted in figure 2.

\section{Automatic Surface-Water Sample Collection}

An automatic water sampler (Sigma 900) was used to collect surface-water samples during periods of intense precipitation, nighttime, or during nonworking hours. At each of the three WQDCSs, a dedicated automatic sampler was installed (fig. 8) and programmed to collect $100 \mathrm{~mL}$ of water every hour, using an onboard peristaltic pump, during specified high-flow events. The pump was connected to an intake immersed in the water column near each multiparameter sensor, and consisted of at least 10 feet (ft) of $3 / 4$-inch (in.) inner diameter Tygon tube with a 3-in. stainless steel screen at the end placed in the water. Before water-sample collection, the sampling line was purged three times by the pump, after which the sample was collected and placed into a $100-\mathrm{mL}$ plastic sample bottle. After water-sample collection, and before the next sample collection, an internal battery-operated mechanism moved the full bottle out of line with the pump's effluent line and put in its place an empty bottle ready to be filled by the next water sample to be collected. To ensure the stability of the water samples after collection, during onsite

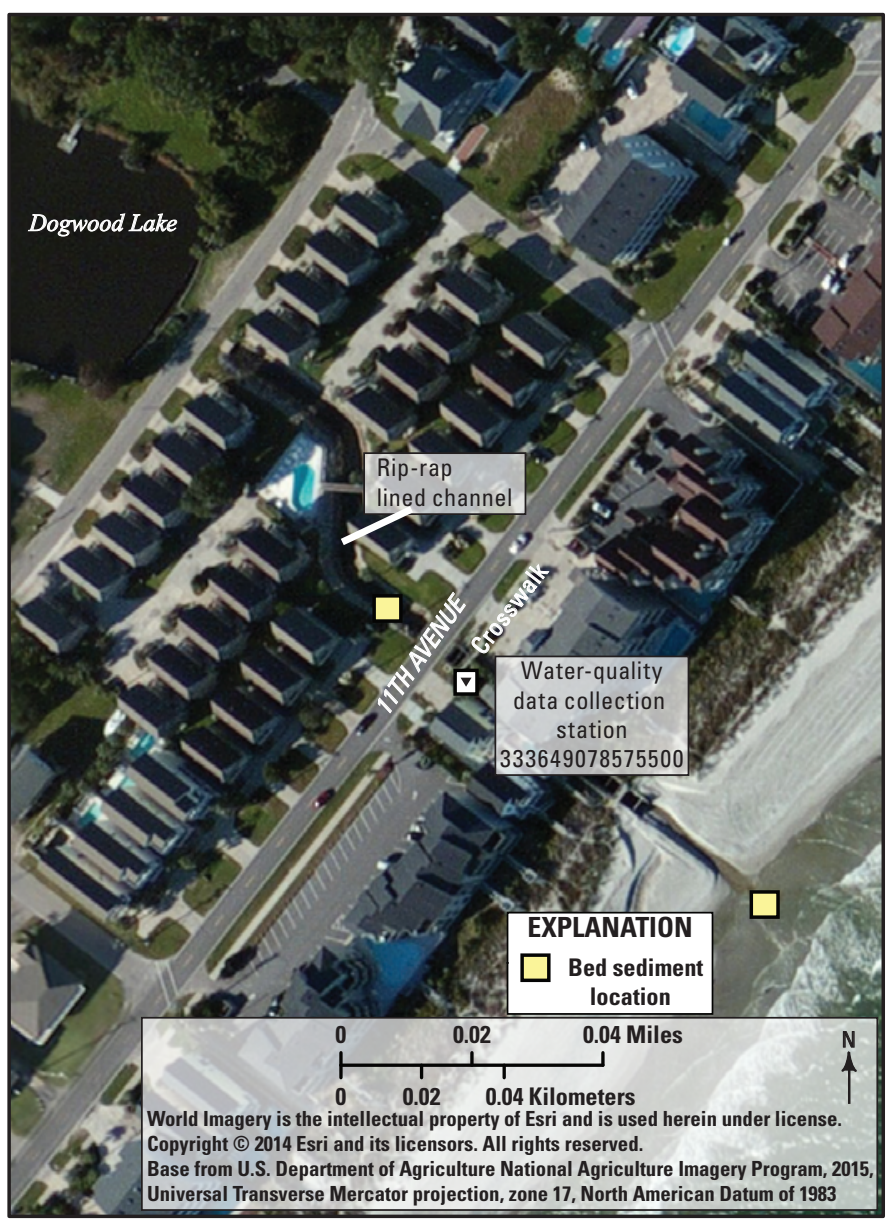

Figure 5. The 11th Avenue crosswalk water-quality data collection station and bed-sediment locations near Surfside Beach, South Carolina. The 12-digit hydrologic unit code for this basin is 030402080307 and is depicted in figure 3.

storage, and before retrieval, a bag of ice was placed inside the enclosed and protected automatic sample-bottle holder rack. Because of the distance between the WQDCSs and the laboratory, and the fact that the samples were collected for research rather than compliance purposes, some samples were processed between 24 and 48 hours of collection; moreover, manual grab samples were collected simultaneously with samples collected automatically to evaluate any differences in Enterococcus concentrations because of the automatic sampler and its longer holding time.

\section{Analysis of Enterococcus Concentrations in Surface-Water Samples}

In the lab, all surface-water samples were analyzed for Enterococcus concentrations by using the Enterolert Quantity-Tray method (IDEXX Laboratories, Westbrook, Maine). The Enterolert method is an EPA-approved method for the detection of enterococci in recreational waters (U.S. Environmental Protection Agency, 2007). The Enterolert method has a detection limit of 1 organism per $100 \mathrm{~mL}$ of 


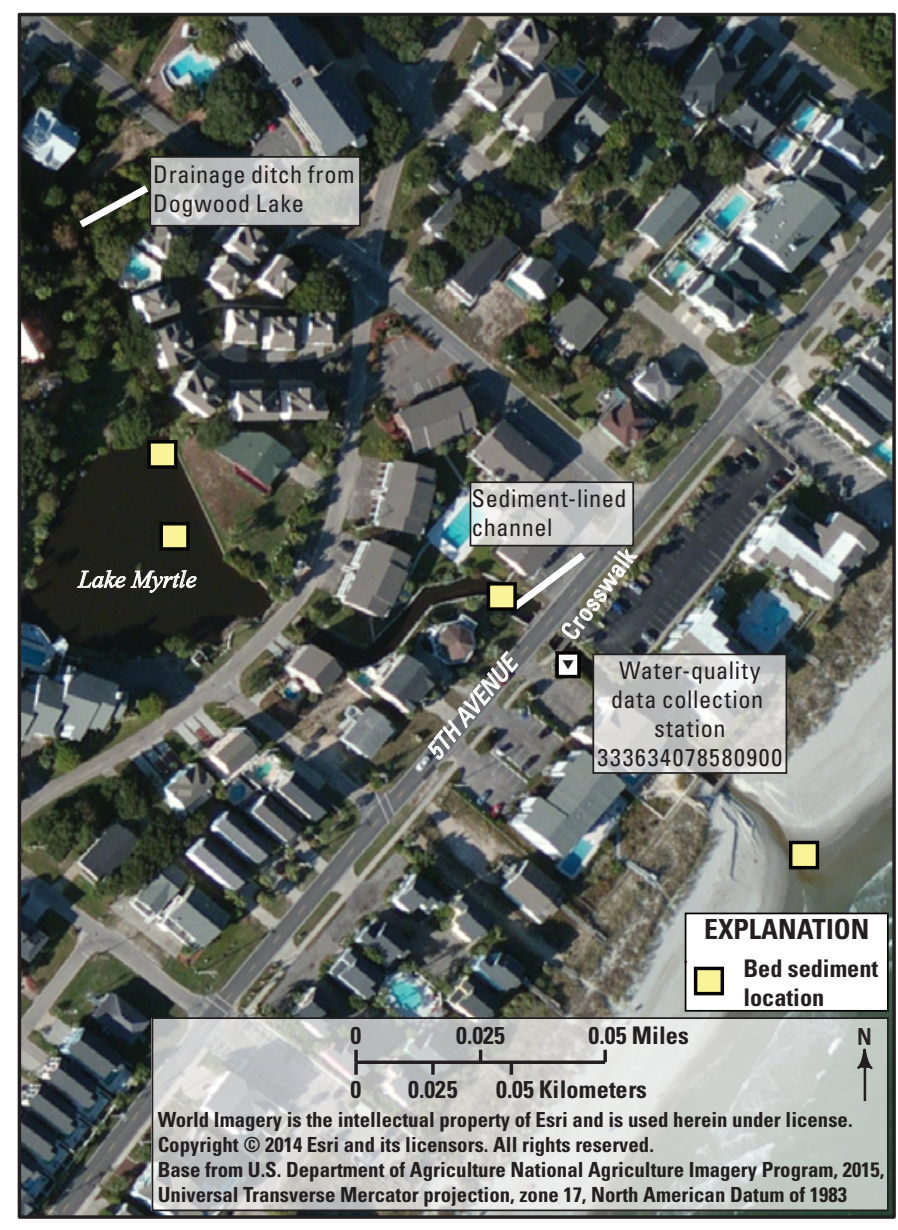

Figure 6. The 5th Avenue crosswalk water-quality data collection station and bed-sediment locations near Surfside Beach, South Carolina. The 12-digit hydrologic unit code for this basin is 030402080307 and is depicted in figure 3.

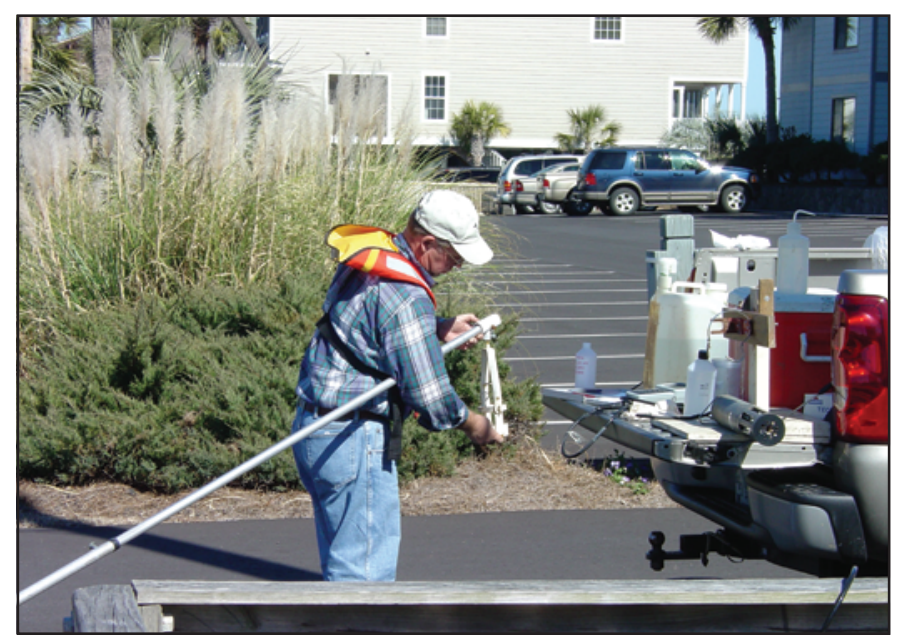

Figure 7. Method used to manually collect surface-water samples by placing a 500-millileter high-density polyethylene bottle in a metal bucket attached to the end of a telescoping pole. (Photograph by J.E. Landmeyer).

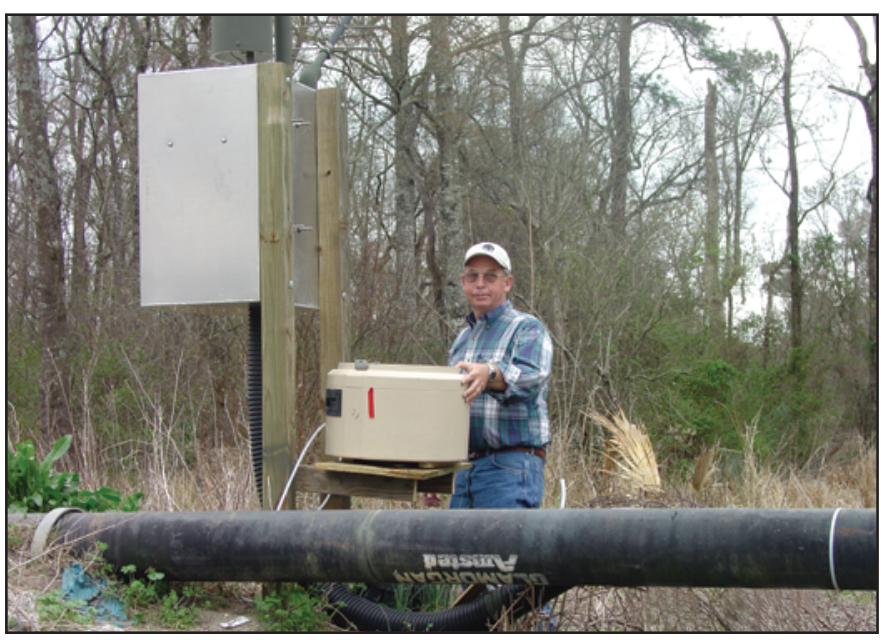

Figure 8. Method used to automatically collect surface-water samples by using an automatic water sampler. The one shown was located at the Highway 707 Bridge water-quality data collection station near Socastee, South Carolina. (Photograph by J.E. Landmeyer).

water. The samples were incubated at 41 degrees Celsius $\left({ }^{\circ} \mathrm{C}\right)$ for 24 hours. The results are reported in most probable number (MPN) per $100 \mathrm{~mL}$ of water (MPN/100 mL). This is analogous to the more commonly used units of colonies/100 $\mathrm{mL}$. The method can detect the following Enterococcus ssp.: faecalis, faecium, avium, gallinarum, casseliflavus, and durans. The method is simple to use (compared to standard plate-count methods), and because detection of enterococci is based on defined substrate technology, fluorescence under exposure to ultraviolet light indicates metabolism by and the presence of enterococci. Because of the distance between the WQDCSs and the laboratory, and the fact that the samples were not collected for compliance purposes, most samples were processed between 24 and 48 hours of collection. A longer holding time is supported by Milligan (1988), in which there was no statistical difference in Enterococcus concentrations for samples collected and analyzed within the 6- and 24-hour holding times.

Water samples collected at the Highway 707 Bridge water-quality data collection station during February or March 2004 did not require a dilution prior to analyses. Water samples collected during August 2004 sampling did require a 1:10 dilution by using autoclaved deionized water. Water samples collected at the 5th Avenue crosswalk water-quality data collection station during July and August 2004 sampling also required a 1:10 dilution by using autoclaved deionized water. The level of Enterococcus in the autoclaved water was analyzed during each sample run.

Enterococcus concentrations in surface-water samples collected using the two methods were evaluated using a relative-percent difference approach. The relative percent difference for a particular sampling event that involved both methods is the ratio of the absolute difference in Enterococcus concentrations for each method to the average difference, multiplied by 100 . 
Relation Between Enterococcus Concentrations and Turbidity in Fresh and Saline Recreational Waters

\section{Sampling and Analysis of Enterococcus Concentrations in Surface-Water Bed Sediments}

During August 2004, bed-sediment samples were collected near the WQDCS at Highway 707 Bridge (fig. 4), and bed sediments and surf-zone beach sands were collected at the 11th Avenue (fig. 5) and 5th Avenue (fig. 6) WQDCSs. During September 2004, bed-sediment samples were collected in Lake Myrtle upstream from the 5th Avenue WQDCS (fig. 6). The bed sediments from Lake Myrtle were collected from a delta that had formed near the inlet to Lake Myrtle created by the drainage canal (ditch) that permits water from Dogwood Lake to flow intermittently to Lake Myrtle. All bed-sediment samples were collected using a flame-sterilized hand auger. The bed sediments were characterized by sediment, surfacewater slurries; and were placed in glass jars, capped, and placed on ice until arrival at the USGS laboratory in Columbia, S.C. In the laboratory, about 30 grams (g) of saturated bed sediment was placed in 100-mL sterilized plastic jars to which was added autoclaved, deionized water to bring the sediment, surface-water slurry up to $100 \mathrm{mLs}$, capped, shaken, and placed in the dark at room temperature and static conditions within 24 hours of sample collection. At periodic intervals, the jars were shaken, $10 \mathrm{~mL}$ of supernatant was pipetted into a sterilized $100-\mathrm{mL}$ plastic jar into which autoclaved deionized water was added to the $100-\mathrm{mL}$ mark. The jars were then recapped and placed back in the dark until the next analysis. Enterolert reagent was added to the vials containing the 100 $\mathrm{mL}$ sample and the Enterococcus concentration determined using the Enterolert method described earlier.

\section{Turbidity Measurements}

At each WQDCS, a multiparameter sonde (Yellow Springs Instruments 6600 sonde) was placed in the water column. The multiparameter sonde was installed inside a 4-in. diameter polyvinyl chloride pipe (fig. 9) such that the sensors would be adjacent to multiple 1-in. diameter holes drilled in the part of the pipe that was submerged below the mean high-water altitude. The pipe was permanently attached to a fixed structure, such as a crosswalk at 5th and 11th Avenues (figs. 10 and 11, respectively) or a pipe at Socastee (fig. 12). This setup allowed the sensors to measure parameters over time at the same depth in the surface water regardless of the height of the surface water. It also protected the probe and sensors from physical harm.

The Yellow Springs Instruments 6600 used the turbidity sensor (6136), which reports turbidity in formazin nephelometric units (FNUs). Unlike the measurement of a physical property of water, such as temperature, the measurement of the turbidity of a water sample is a measurement of the degree of scattering of incident light as it passes through the water sample. The type of light source and detector used to measure turbidity is important, and there can be considerable variation

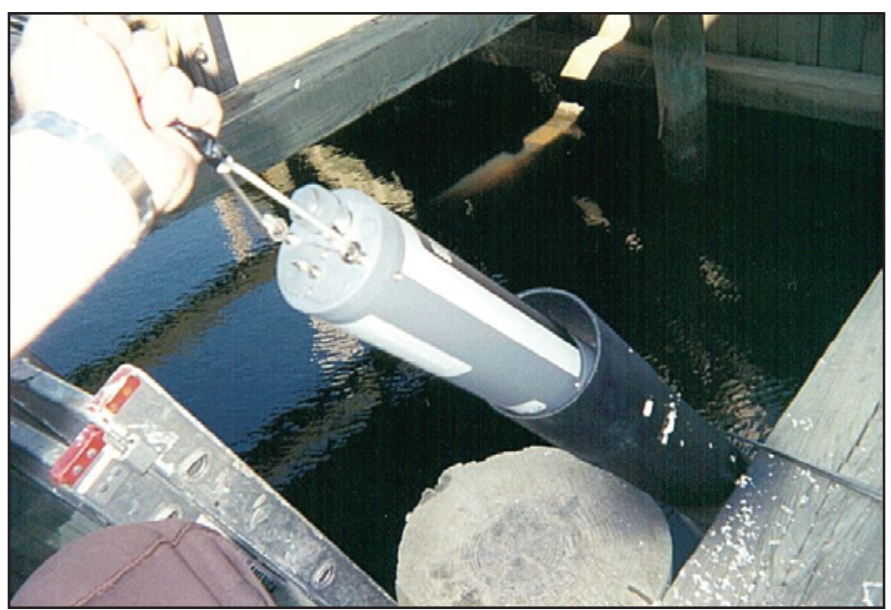

Figure 9. Multiparameter sonde being installed in the polyvinyl chloride pipe open to the surface-water column, 11th Avenue crosswalk water-quality data collection station near Surfside Beach, South Carolina. (Photograph by J.E. Landmeyer).

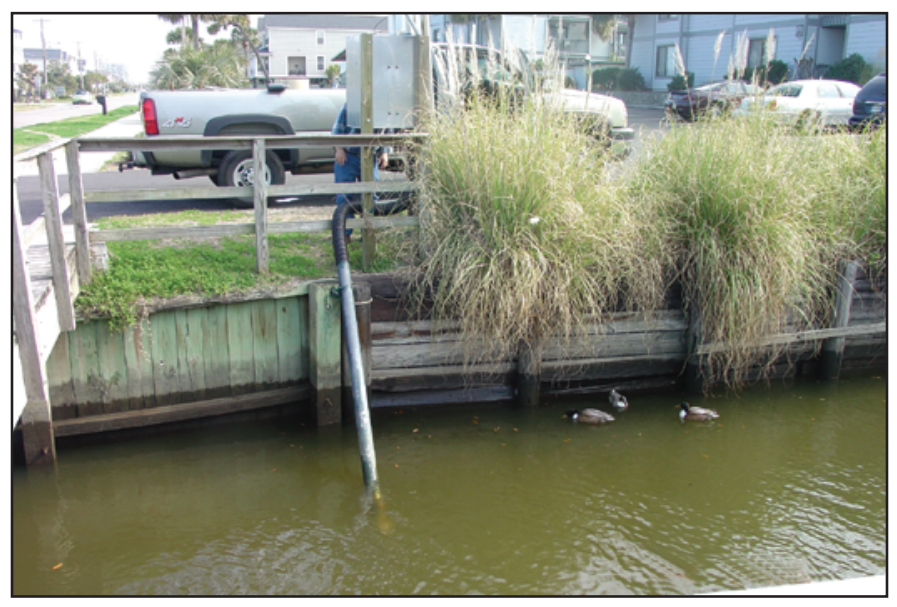

Figure 10. Water-quality data collection station installed at the 5th Avenue crosswalk near Surfside Beach, South Carolina. (Photograph by J.E. Landmeyer).

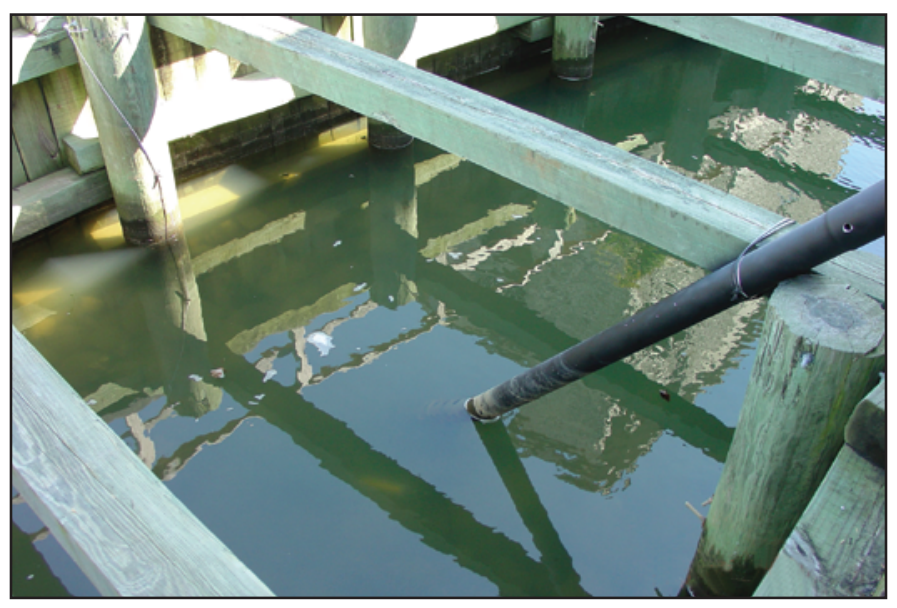

Figure 11. Water-quality data collection station installed at the 11th Avenue crosswalk near Surfside Beach, South Carolina. (Photograph by J.E. Landmeyer). 


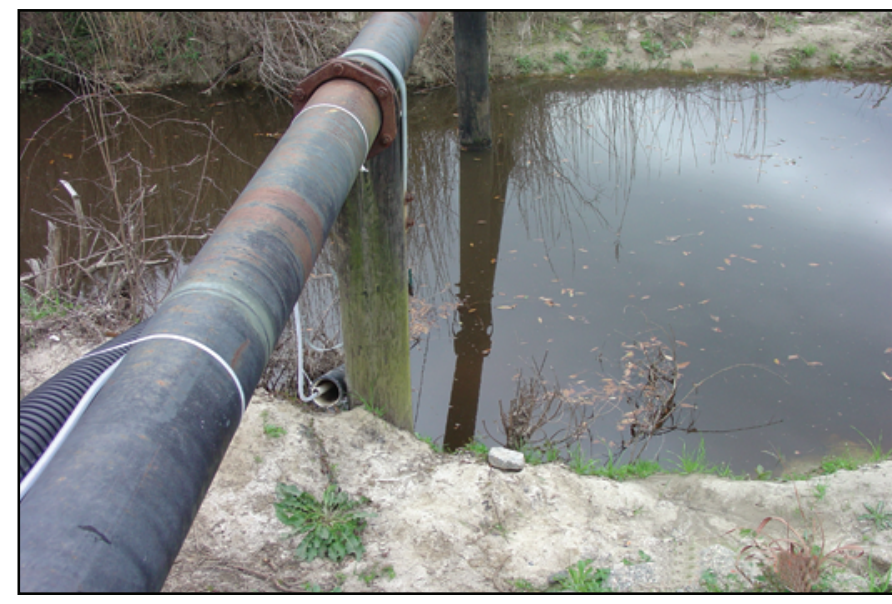

Figure 12. Water-quality data collection station installed at Highway 707 Bridge near Socastee, South Carolina. (Photograph by J.E. Landmeyer).

in results reported for turbidity for the same water sample using different probes. The EPA has released a standard method for the measurement of turbidity in drinking water, method 180.1 (U.S. Environmental Protection Agency, 1993). The International Organization for Standardization also has released a method (7027) that established instrument standards for turbidity probes. In general, the EPA method reports turbidity in nephelometric turbidity units, compared to the International Organization for Standardization method, which uses FNUs. The differentiation between units is to recognize the use of different detectors that detect the extent of light scattering and, therefore, the reported turbidity value. Turbidity values for this investigation are reported in FNUs.

The Yellow Springs Instruments 6600 sonde also measured dissolved oxygen [in milligrams per liter $(\mathrm{mg} / \mathrm{L})]$, $\mathrm{pH}$, temperature [in degrees Celsius $\left({ }^{\circ} \mathrm{C}\right)$ ], oxidation-reduction potential [in millivolts $(\mathrm{mV})$ ], and specific conductivity (in $\mu \mathrm{S} / \mathrm{cm}$ ). Turbidity and all other parameters were measured on a 15-minute interval, and recorded on a data logger

(Sutron 8210) attached to the sonde by a cable and enclosed in a protective shed. Some continuous water-quality data (such as surface-water temperature, $\mathrm{pH}$, oxidation-reduction potential, and wind speed and direction) were collected and used to help interpret the bacterial levels being measured. Each WQDCS was equipped with a tipping-bucket rain gage used to measure instantaneous precipitation measured hourly and sensors that measured wind speed and direction, all attached to the top of each protective shed. Data collected and stored at each WQDCS were transmitted to the USGS office in Columbia, S.C., by satellite transmission, and the data were stored in the USGS National Water Information System (NWIS). In order to maintain strict quality control and assurance of the data being reported by each WQDCS during the length of the study, all sensors for each of the probes at all water-quality data collection stations were calibrated using standard techniques every 2 weeks after initial deployment (USGS, variously dated).

\section{Relation Between Enterococcus Concentrations and Turbidity}

The period of June-August 2003 when the WQDCSs were installed was characterized by little precipitation. In contrast, multiple tropical depressions, hurricanes, and attendant higher precipitation amounts characterized the same months in 2004 (appendix 1, tables 1-1, 1-2, and 1-3).

\section{Atlantic Intracoastal Waterway, Socastee, South Carolina}

Measurements of precipitation, turbidity, and Enterococcus concentrations in surface-water samples were made at the Highway 707 Bridge WQDCS during February 19-20, March 8-10, and August 12-18, 2004. The relations between Enterococcus concentration and turbidity for each sampling period are described below.

\section{February 2004}

Measurements of precipitation, turbidity, and Enterococcus concentrations in surface-water samples collected at the Highway 707 Bridge WQDCS during February 19-20, 2004, are shown in figure 13. The 2-day period had no precipitation. There is a positive relation between Enterococcus concentrations in surface-water samples collected manually and automatically; that is, the lowest and highest Enterococcus concentrations in manually collected samples corresponded to the lowest and highest Enterococcus concentrations in automatically collected samples. The average relative-percent difference between the absolute values of Enterococcus concentrations in surface-water samples collected using the two methods, however, was significantly different at 41 percent (appendix table 1-1). The ability for the automatic sampler to collect more surface-water samples, however, revealed that enterococci increased during the 2-day sampling period even though no precipitation was recorded.

The data for Enterococcus concentrations and turbidity were $\log$ transformed to achieve a more linear fit. Enterococcus concentrations measured in surface water were not positively related to turbidity during this 2-day time period in February 2004 (fig. 14). In fact, the highest turbidity values were measured when Enterococcus concentrations were lowest, and the lowest values of turbidity were measured when the values of Enterococcus concentrations were the highest.

\section{March 2004}

Measurements of precipitation, turbidity, and Enterococcus concentrations in surface-water samples collected at the Highway 707 Bridge WQDCS during March 8-10, 2004, are shown in figure 15. The 3-day period included a dry day with little precipitation and a precipitation event that amounted to less than 1 in. on late March 9 and early March 10, 2004 (fig. 15). 


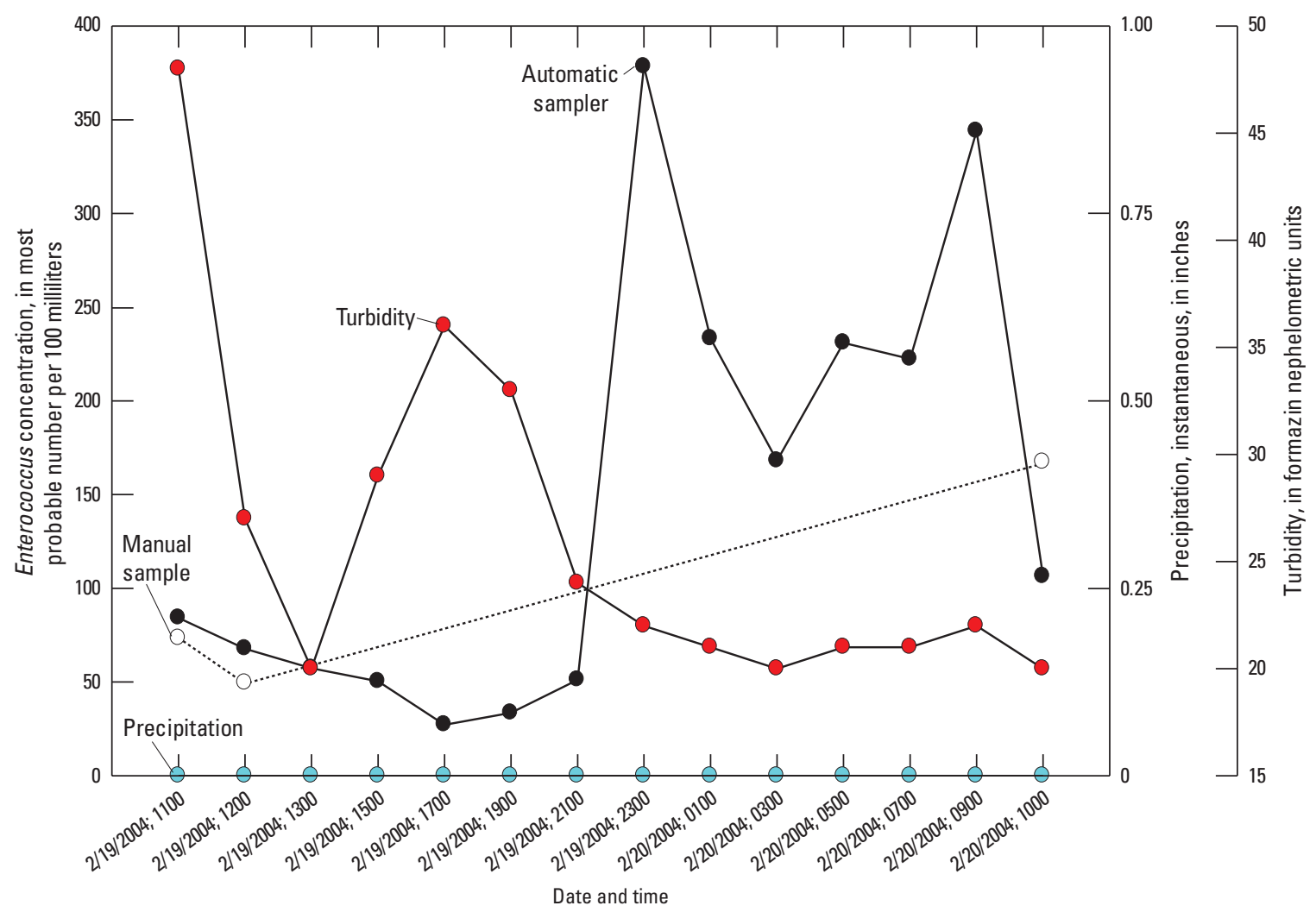

Figure 13. Enterococcus concentration in surface-water samples collected using manual and automatic water-sample collection approaches, precipitation, and turbidity, February 19-20, 2004, Highway 707 Bridge water-quality data collection station near Socastee, South Carolina.

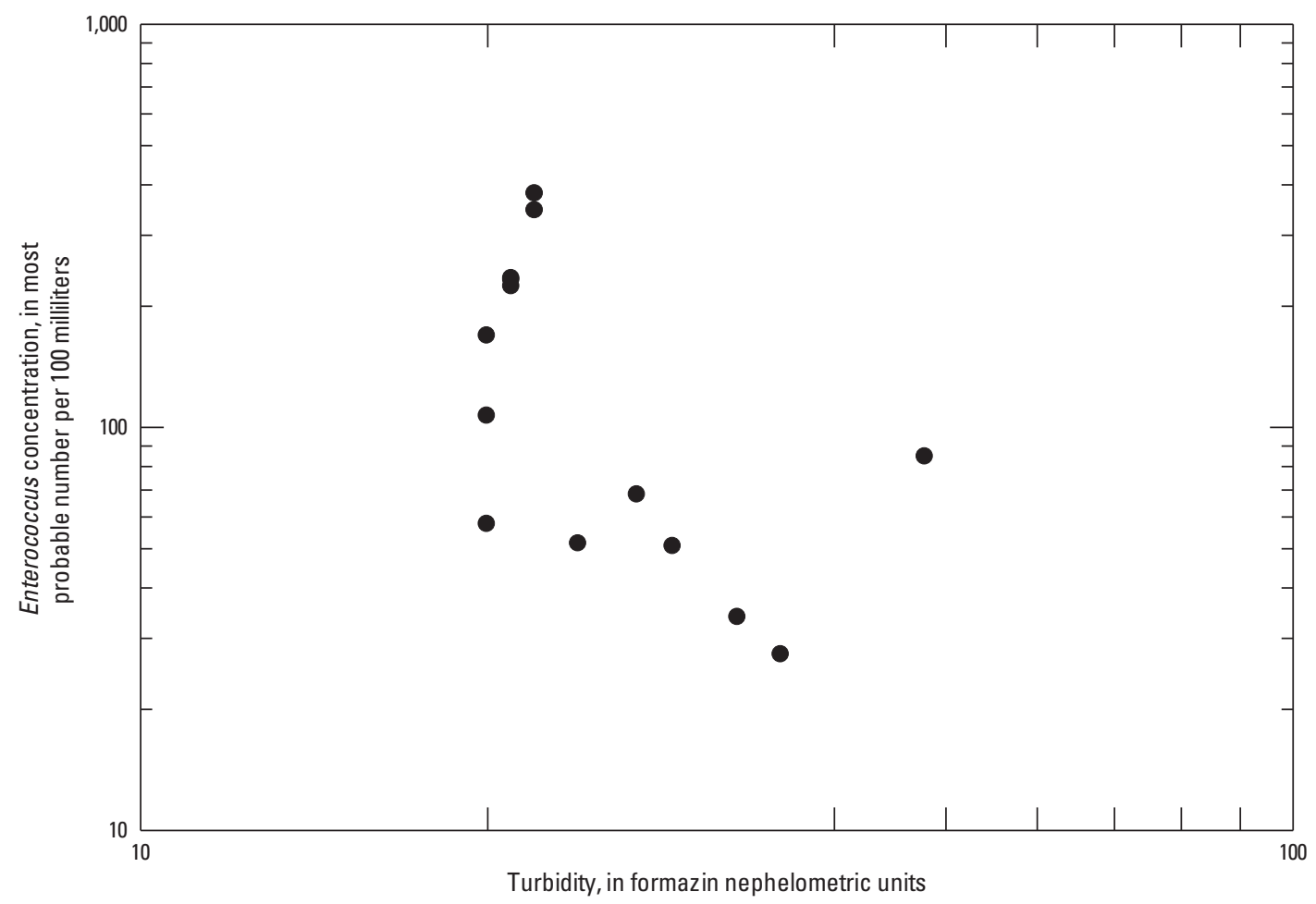

Figure 14. Enterococcus concentration in surface-water samples collected using the automatic sampler compared to turbidity measurements, February 19-20, 2004, Highway 707 Bridge water-quality data collection station near Socastee, South Carolina. 


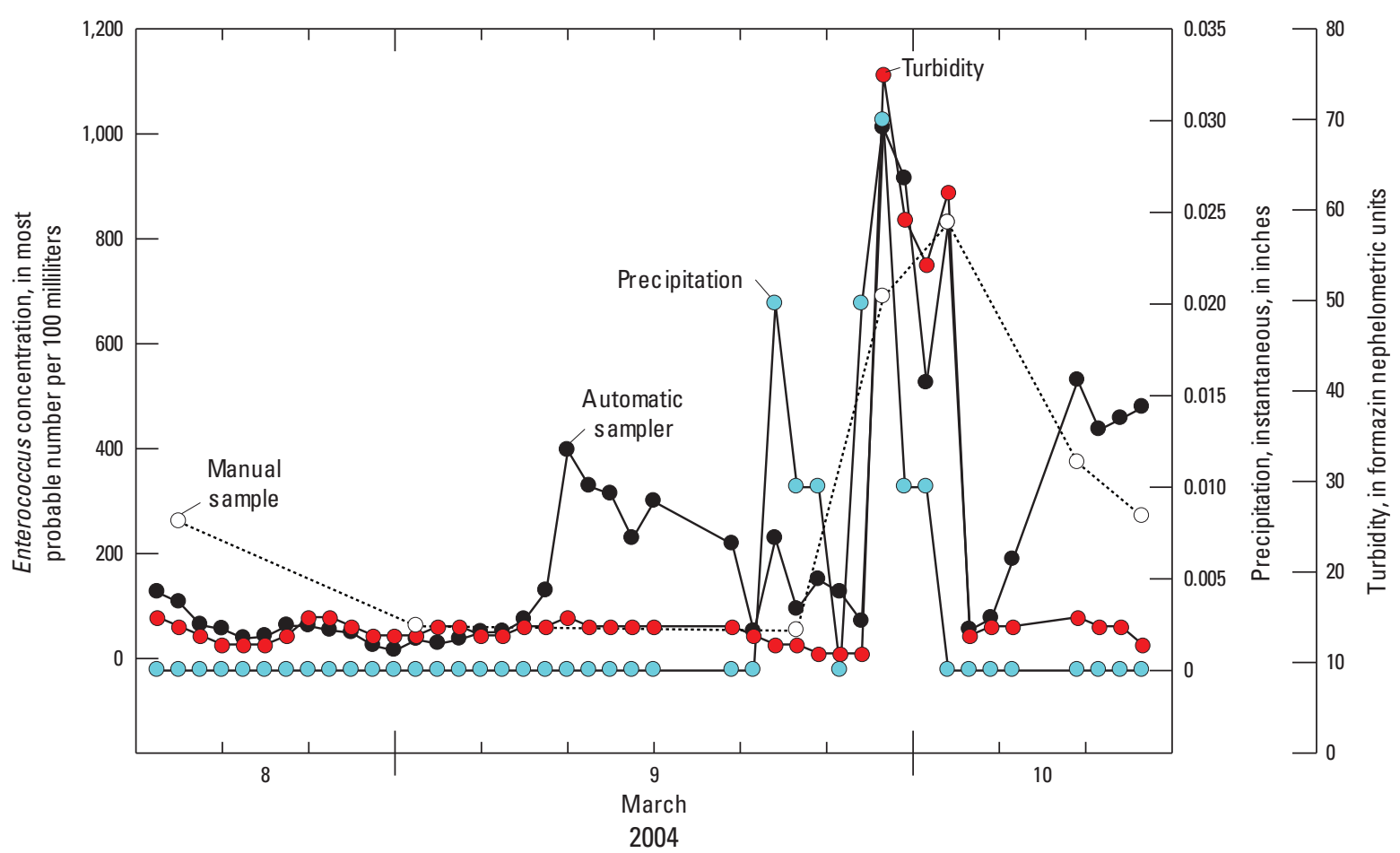

Figure 15. Enterococcus concentration in surface-water samples collected using an automatic sampler, precipitation, and turbidity before, during, and after a precipitation event, March 8-10, 2004, Highway 707 Bridge water-quality data collection station near Socastee, South Carolina.

On March 8, 2004, the Enterococcus concentrations in the surface-water samples collected manually were no greater than $260 \mathrm{MPN} / 100 \mathrm{~mL}$ (appendix table 1-1). During this time, there is a positive relation between Enterococcus concentrations in surface-water samples collected automatically and Enterococcus concentrations in surface-water samples collected manually, although the average relative-percent difference between the absolute values of Enterococcus concentrations collected using the two methods was significantly different at 46 percent (appendix table 1-1). Although the levels of Enterococcus concentrations showed an increase in the hourly surface-water samples collected automatically when no precipitation had fallen (as was observed during sampling at this location in February 2004), the surface-water sample collected manually early March 9, 2004, indicated the lowest value for Enterococcus concentrations (52.71 MPN/100 mL) of the samples collected before the precipitation event. Both surface-water sample collection methods examined, however, indicated that the arrival of the precipitation event late in the day on March 9, 2004, resulted in an increase in Enterococcus concentrations (fig. 15). After the precipitation event ended, surface-water samples collected using both methods indicated lower, but not quite pre-precipitation, Enterococcus concentrations (fig. 15). In fact, the Enterococcus concentrations in the automatically collected surface-water samples increased within a few hours after the end of precipitation to be about one-half of the levels observed during precipitation (fig. 15). This increase in Enterococcus concentrations in surface-water samples collected after the precipitation event had ended is most likely because of the flow of surface water that was derived from upstream parts of the drainage basin and characterized by runoff from the precipitation event, or the movement of bed sediment that contained enterococci in the channel from upstream areas. Enterococcus concentrations in surface-water samples were at the highest levels when the value of turbidity in surface water also was the highest during this 3-day sampling period (fig. 15). Unlike the Enterococcus concentrations, however, the values of turbidity rapidly decreased after precipitation ceased.

A positive relation was observed between Enterococcus concentrations in surface-water samples and turbidity during March 8-10, 2004, at the Highway 707 Bridge WQDCS (fig. 16); that is, surface-water samples characterized by higher turbidity also had higher Enterococcus concentrations. In contrast, there was little relation between Enterococcus concentrations in surface-water samples and precipitation (fig. 17); that is, surface-water samples characterized by higher Enterococcus concentrations were not always related to high precipitation amounts because precipitation occurred with no increase in Enterococcus concentration.

\section{August 2004}

Measurements of precipitation, turbidity, and Enterococcus concentrations in surface-water samples collected during August 12-18, 2004, at the Highway 707 Bridge WQDCS are shown in figure 18. During this time, Tropical Depression 


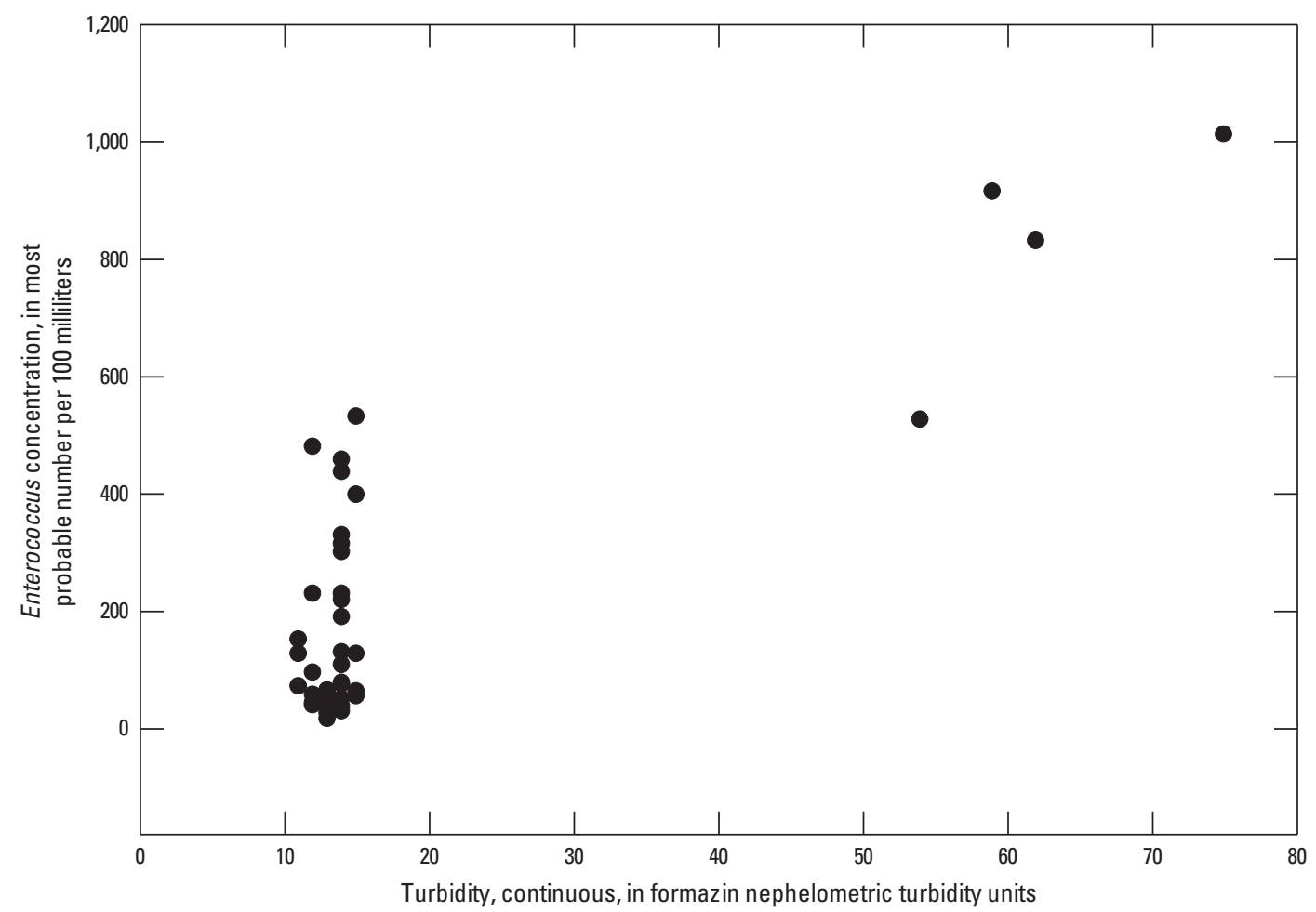

Figure 16. Enterococcus concentration in surface-water samples collected automatically compared to turbidity measurements, March 8-10, 2004, Highway 707 Bridge water-quality data collection station near Socastee, South Carolina.

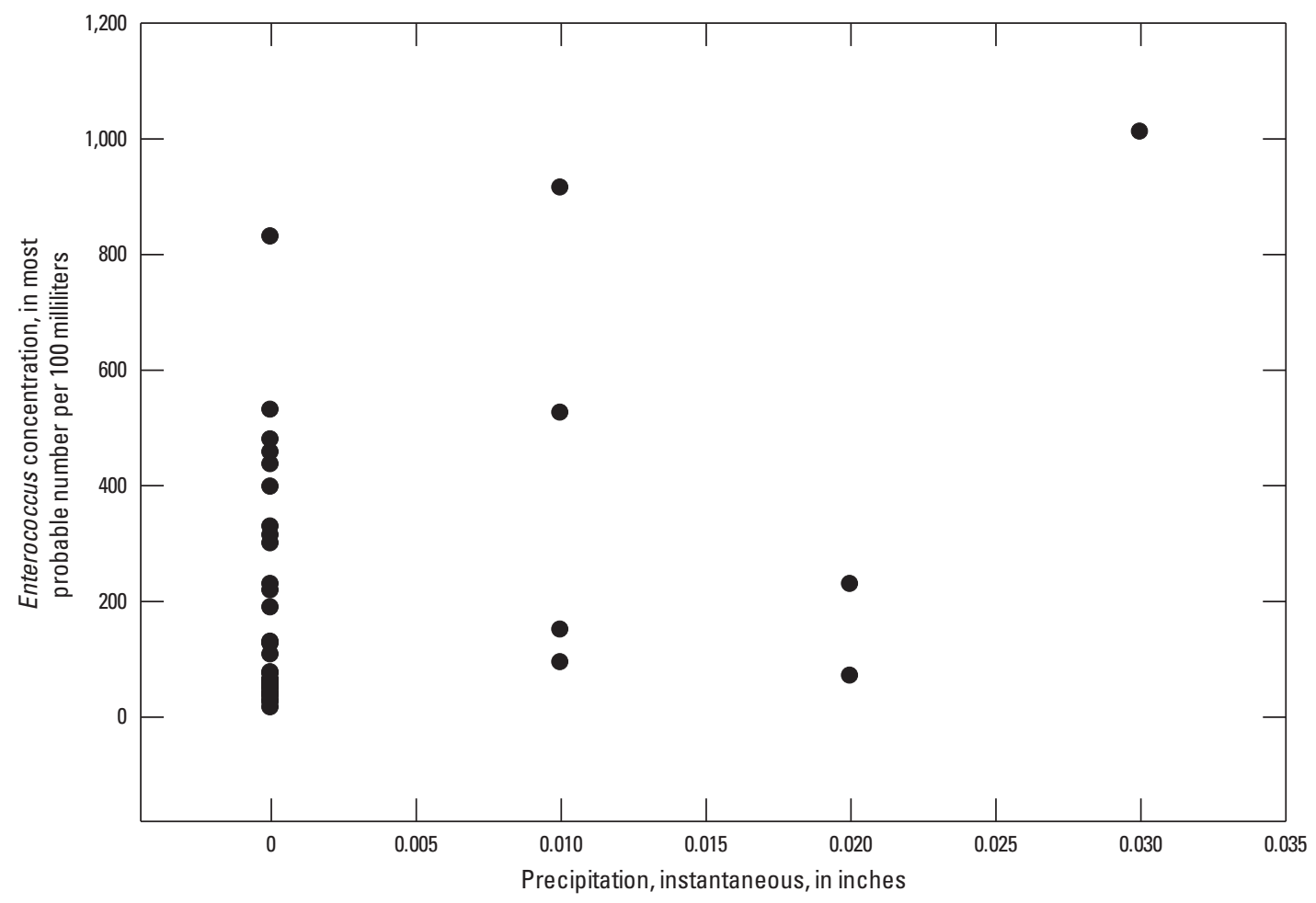

Figure 17. Enterococcus concentration in surface-water samples collected automatically compared to precipitation, March 8-10, 2004, Highway 707 Bridge water-quality data collection station near Socastee, South Carolina. 
Bonnie came through the coastal area of Horry County, S.C., and brought as much as 4 in. of precipitation in some parts of the study area, along with another 4 in. of precipitation during August 14-15 with the arrival of Category 1 Hurricane Charley (fig. 18). Much of the precipitation occurred in the late afternoon to late evening on August 12 for a total of about 4 in. within a 12-hour period in the study area. Friday, August 13 was relatively quiet with little precipitation. This scenario changed on Saturday August 14 and Sunday August 15 when Hurricane Charley arrived in Horry County, S.C. An additional 4 in. of precipitation fell in the study area within a few hours on August 14 and again on August 15. The precipitation, and its intensity (most fell within a few hours), is reflected in the increase in the Enterococcus concentrations measured in surface-water samples collected automatically at the Highway 707 Bridge WQDCS (fig. 18). These storms also increased turbidity from background levels of less than $10 \mathrm{FNU}$ to more than 600 FNU during the storm (fig. 18).

The initial surface-water samples collected were characterized by low Enterococcus concentrations, which is representative of normal, dry conditions. These low bacterial levels ended abruptly, however, by the afternoon of Thursday, August 12, when Enterococcus concentrations went from $74 \mathrm{MPN} / 100 \mathrm{~mL}$ to greater than 24,192 MPN/100 mL within 2 hours. This increase was a result of the arrival of precipitation that afternoon. Turbidity also quickly increased from 0 FNU to almost 200 FNU (fig. 18). High Enterococcus concentrations in surface-water samples were observed and continued until the next day, when Enterococcus concentrations decreased from greater than 24,192 MPN/100 mL to $119 \mathrm{MPN} / 100 \mathrm{~mL}$ on August 13 (fig. 18). At that time, turbidity was still high, but returned to normal low levels by late August 13. The most likely explanation for such a rapid increase in Enterococcus concentrations in surface-water samples is the resuspension of bed sediments into the water column rather than runoff. This explanation is warranted because the increase in bacteria took less than 2 hours, and far more time would be required for the drainage basin to receive recent runoff to account for these increases in Enterococcus concentrations. During this period of sample collection, there is a positive relation between Enterococcus concentrations reported in surface-water samples collected by the automatic sampler and Enterococcus concentrations reported in surface-water samples collected manually, although the average relative percent difference between the absolute values of enterococci in surface-water samples collected using the two methods was significantly different at 52 percent (appendix table 1-1).

The relation between continuously measured turbidity and Enterococcus concentrations in surface-water samples collected for this period in August 2004 at the Highway 707 Bridge WQDCS was evaluated (fig. 19). The data for Enterococcus concentrations and turbidity were log transformed to achieve a more linear fit. In general, there was a positive relation between turbidity and Enterococcus concentrations; that is, higher values of turbidity are associated with higher Enterococcus concentrations.

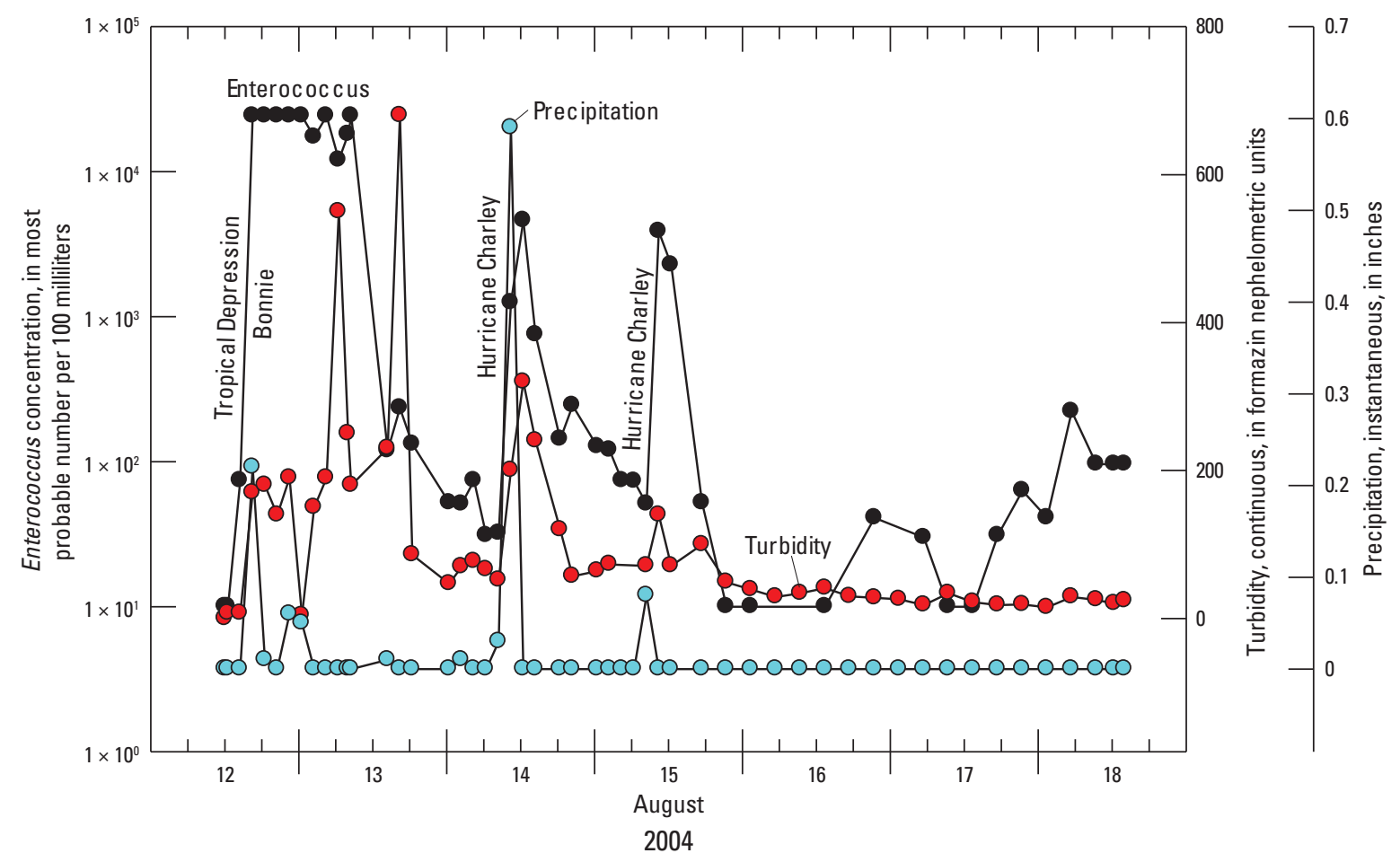

Figure 18. Enterococcus concentration in surface-water samples collected using manual and automatic water-sample collection approaches, precipitation, and turbidity, August 12-18, 2004, Highway 707 Bridge water-quality data collection station near Socastee, South Carolina. The Enterococcus concentrations are log transformed. 


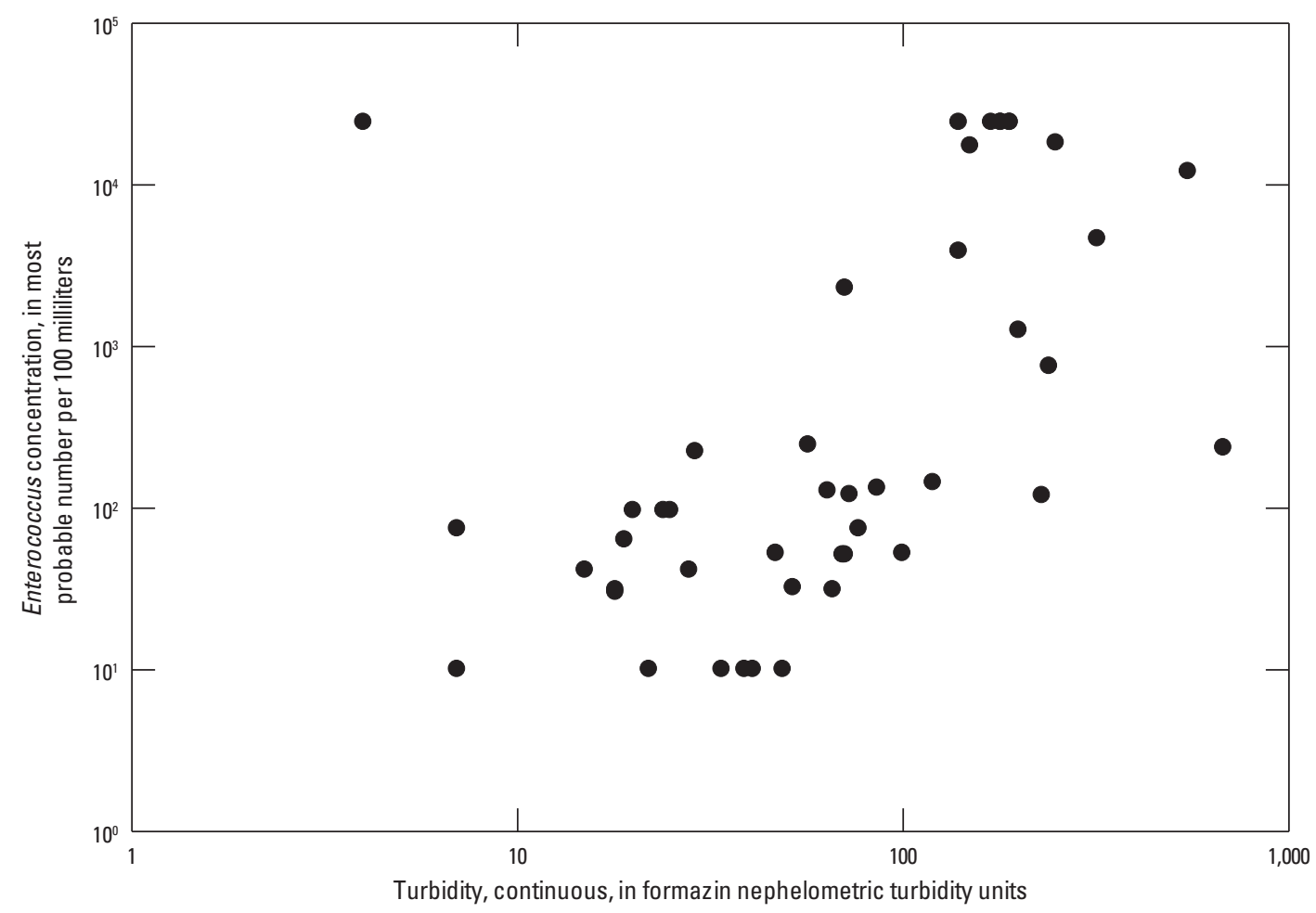

Figure 19. Enterococcus concentration in water samples collected using the automatic sample collector compared to turbidity, August 2004, Highway 707 Bridge water-quality data collection station near Socastee, South Carolina.

\section{Atlantic Ocean Surf Zone, Surfside Beach, South Carolina}

\section{July 2004}

Measurements of precipitation, turbidity, and Enterococcus concentrations in surface-water samples collected at the 5th Avenue crosswalk WQDCS during July 15-18, 2004, are shown in figure 20. This sampling event occurred during no recorded precipitation. During such dry periods, freshwater from Lake Myrtle flows seaward past the WQDCS (fig. 6). This seaward flow of freshwater is affected, however, by the landward flow of seawater in response to changes in the tides. This effect of tide on water quality, specifically turbidity and Enterococcus concentration, is discussed.

On July 18, 2004, a high tide resulted in the landward propagation of high specific conductance seawater past the WQDCS, and the turbidity decreased rapidly as a result (fig. 20). The lower turbidity values of the seawater remained even following reversal of the tide to low conditions as the higher specific conductance (and lower turbidity) seawater became trapped in the channel during this period of no recorded precipitation. When the seaward flow of water returned under low tide conditions, turbidity increased later in the day on July 18, 2004, reflecting the flow of fresher (higher turbidity) water from Lake Myrtle to the surf.

Because of this interface between freshwater of higher turbidity with saltwater of lower turbidity, there was little positive relation between turbidity and Enterococcus concentrations (fig. 21); that is, higher values of turbidity were not necessarily associated with higher Enterococcus concentrations. The control of the tides on water quality was more pronounced most likely because of the lack of precipitation at the site.

\section{August 2004}

Measurements of precipitation, turbidity, and Enterococcus concentrations in surface-water samples collected at the 5th Avenue crosswalk WQDCS during August 12-18, 2004, are shown in figure 22. The first few surface-water samples had low Enterococcus concentrations and represented dry conditions (fig. 22). These low numbers ended abruptly, however, on late Thursday, August 12, with the arrival of precipitation across the study area, and Enterococcus concentrations went from $50 \mathrm{MPN} / 100 \mathrm{~mL}$ to greater than 5,000 MPN/100 mL within 2 hours (fig. 22). Turbidity also increased from 0 FNU to almost $30 \mathrm{FNU}$ (fig. 22). Enterococcus concentrations decreased after precipitation ended, unlike for the Highway 707 Bridge WQDCS, where high Enterococcus concentrations continued to be measured the day after precipitation had ended; however, late on August 12 and following precipitation, Enterococcus concentrations increased again and then decreased when precipitation ended early August 13. Enterococcus concentrations and turbidity remained low most of August 13 until mid-morning on August 14, during another precipitation event, when turbidity increased from 20 to $100 \mathrm{FNU}$, and Enterococcus concentrations increased from less than $10 \mathrm{MPN} / 100 \mathrm{~mL}$ to more than 


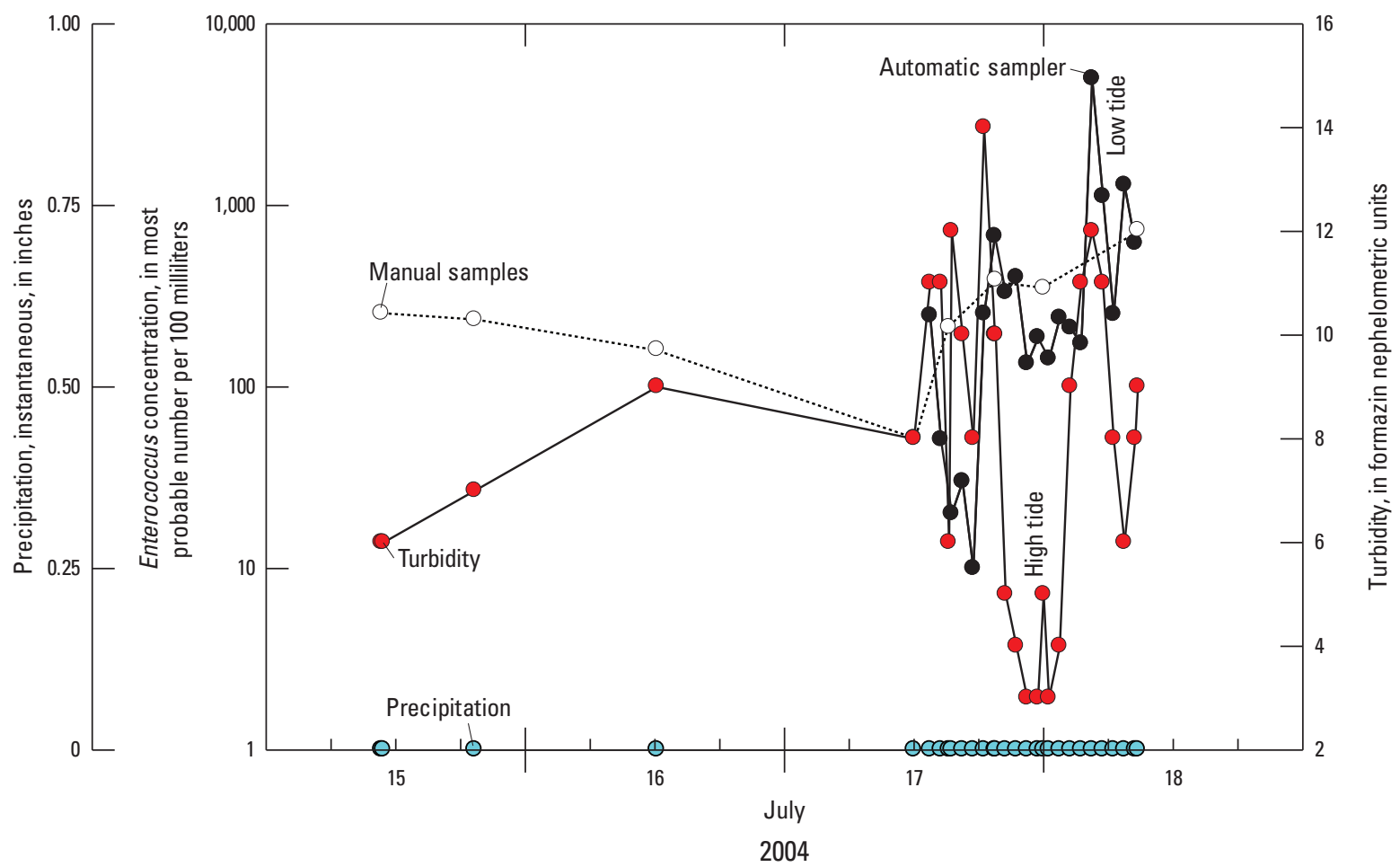

Figure 20. Enterococcus concentration in surface-water samples collected using manual and automatic water-sample collection methods, precipitation, and turbidity, July 15-19, 2004, 5th Avenue crosswalk water-quality data collection station near Surfside Beach, South Carolina. The Enterococcus concentrations are log transformed.

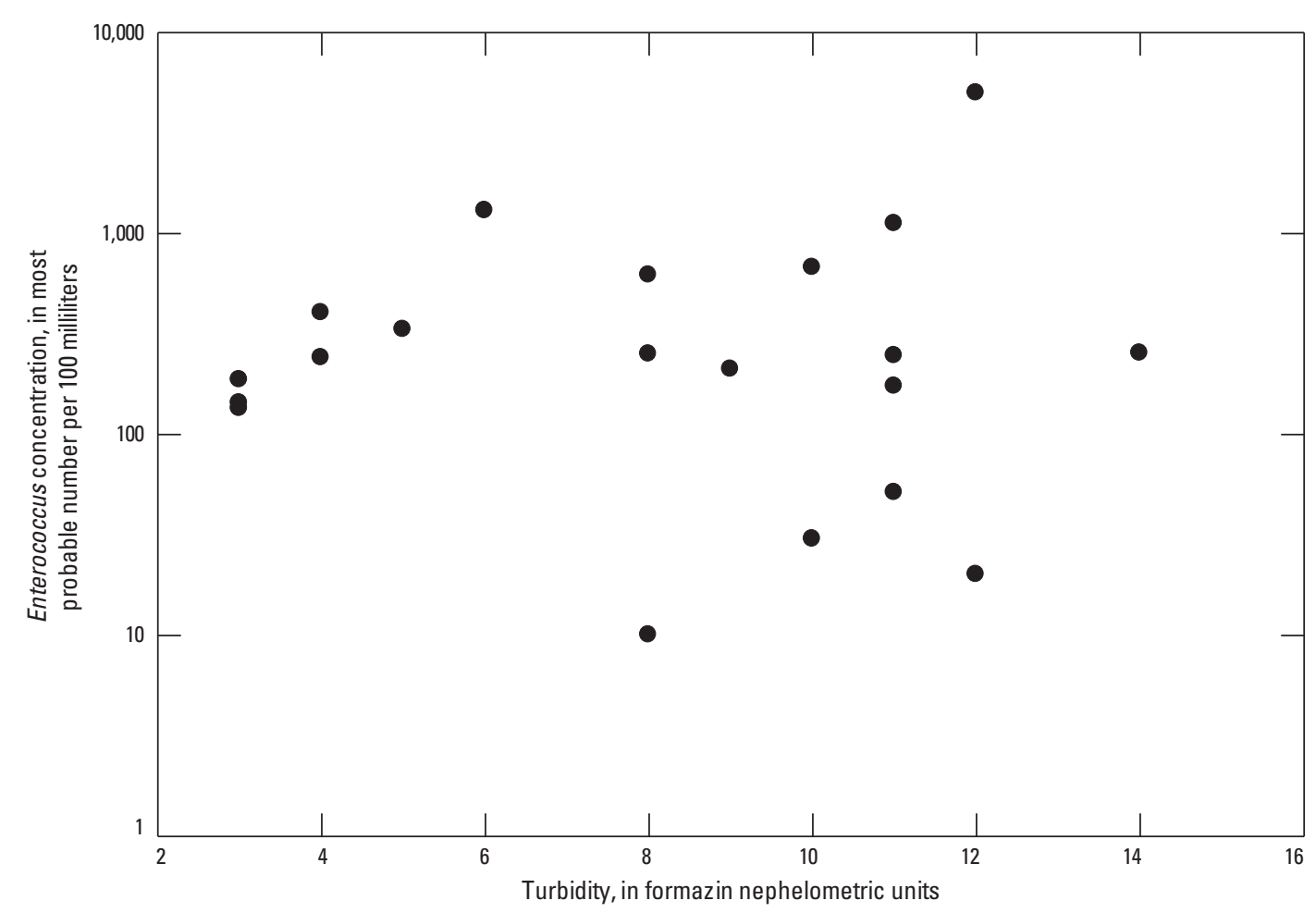

Figure 21. Enterococcus concentration in surface-water samples compared to turbidity, July 2004, 5th Avenue crosswalk water-quality data collection station near Surfside Beach, South Carolina. 


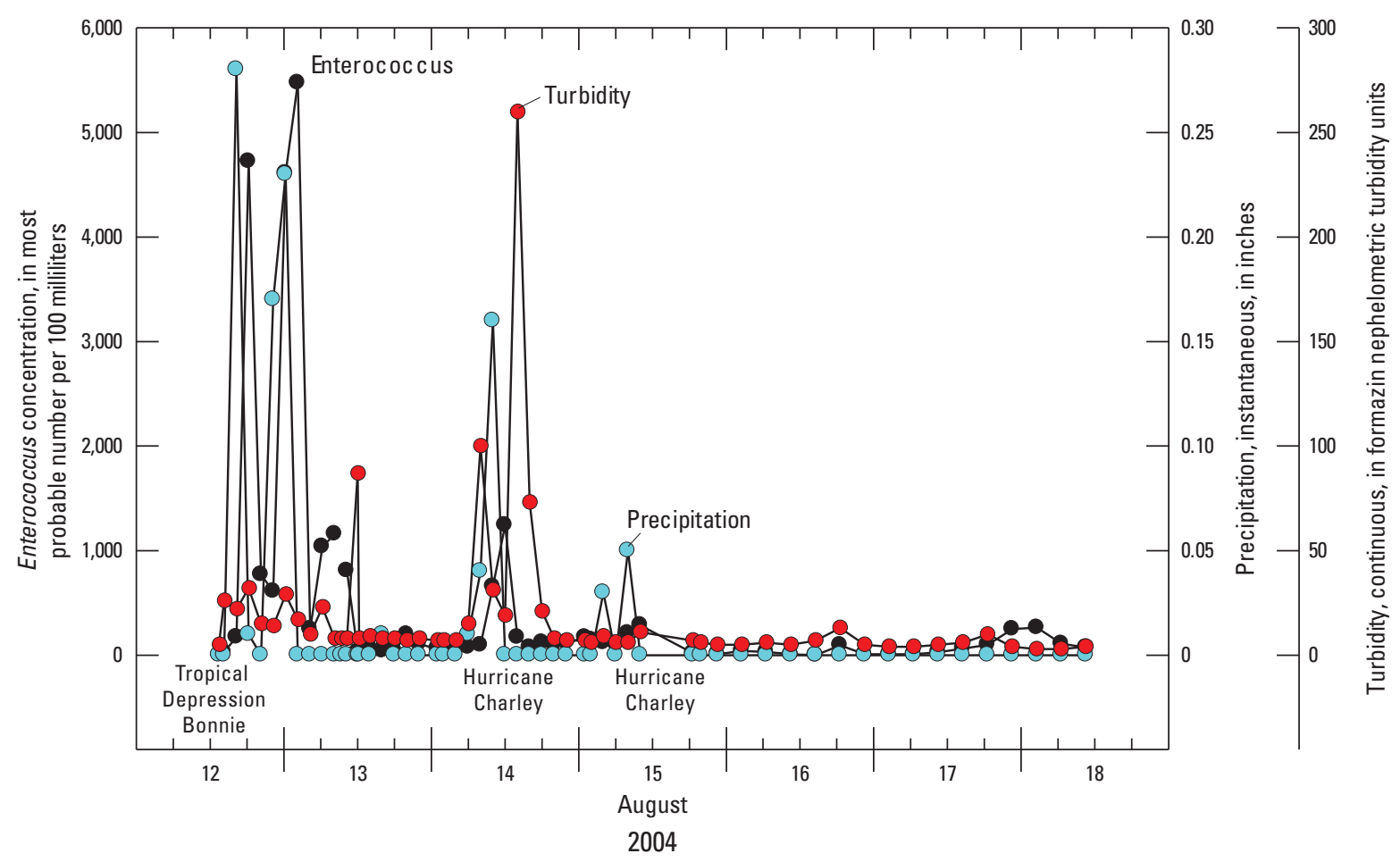

Figure 22. Enterococcus concentration collected using the automatic sample collector compared to precipitation and turbidity, August 2004, 5th Avenue crosswalk water-quality data collection station near Surfside Beach, South Carolina.

1,500 MPN/100 mL. Interestingly, turbidity continued to increase long after the precipitation had ended with the highest turbidity measured late in the afternoon on August 14, at least 4 hours after the precipitation had ended. These high turbidity values returned to normal, lower values with 4 hours. It is notable that the maximum increase in turbidity was higher by an order of magnitude at the Highway 707 Bridge WQDCS than at the 5th Avenue crosswalk WQDCS for the same precipitation event, which most likely reflects the greater bedsediment load in the swamp relative to the more residential area adjacent to the 5th Avenue crosswalk WQDCS.

The relation between measurements of turbidity and Enterococcus concentrations in surface-water samples collected during August 2004 at the 5th Avenue crosswalk WQDCS was examined (fig. 23). The data were log transformed to achieve a more linear fit. There was little positive relation between turbidity and Enterococcus concentrations; that is, higher values of turbidity were not associated with higher Enterococcus concentrations.

The specific conductance measured in surface water during these precipitation events in August 2004 was significantly lower than that measured at the same location during July 2004 when no precipitation was recorded. The lower specific conductance values measured during this time of precipitation has at least two possible explanations. First, the specific conductance could be lower because the surface-water composition is dominated by the seaward flow of freshwater from Lake Myrtle and precipitation, such that even during high tide the specific conductance was low (fig. 24). The seaward flow of freshwater was present in the turbidity values, which were observed to be high during low tide conditions that enhance the seaward flow of freshwater from Lake Myrtle (fig. 24). Conversely, lower turbidity values were measured during high tide when seawater flowed landward (fig. 24). Lower turbidity values of the seawater remained as the water drained seawater under the influence of low tide conditions. Second, the flow of freshwater from Lake Myrtle and precipitation seaward could be vertically displacing the freshwater-saltwater wedge deeper into the channel. Because the sonde position in the water column is fixed, the denser seawater is displaced to an altitude lower than the sonde specific conductance probe.

\section{Surface-Water Bed Sediments as a Source of Enterococcus to Fresh and Saline Recreational Waters}

Surface-water bed sediments collected from the channel at the Highway 707 Bridge WQDCS showed high initial Enterococcus concentrations that remained unchanged even after 4 months of incubation (fig. 25). Similar initial, high 


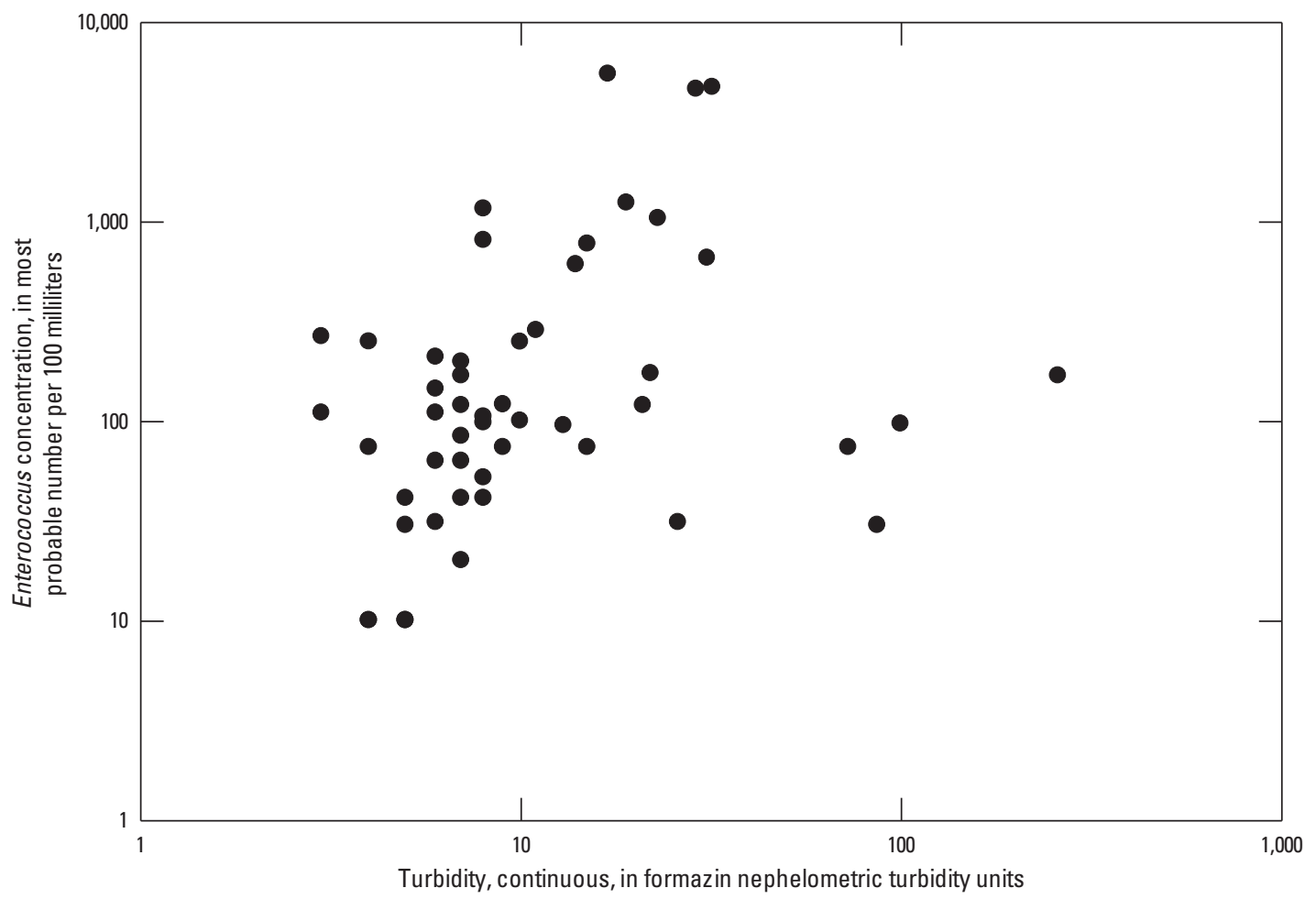

Figure 23. Enterococcus concentration in surface-water samples compared to turbidity, August 2004, 5th Avenue Crosswalk water-quality data collection station near Surfside Beach, South Carolina.

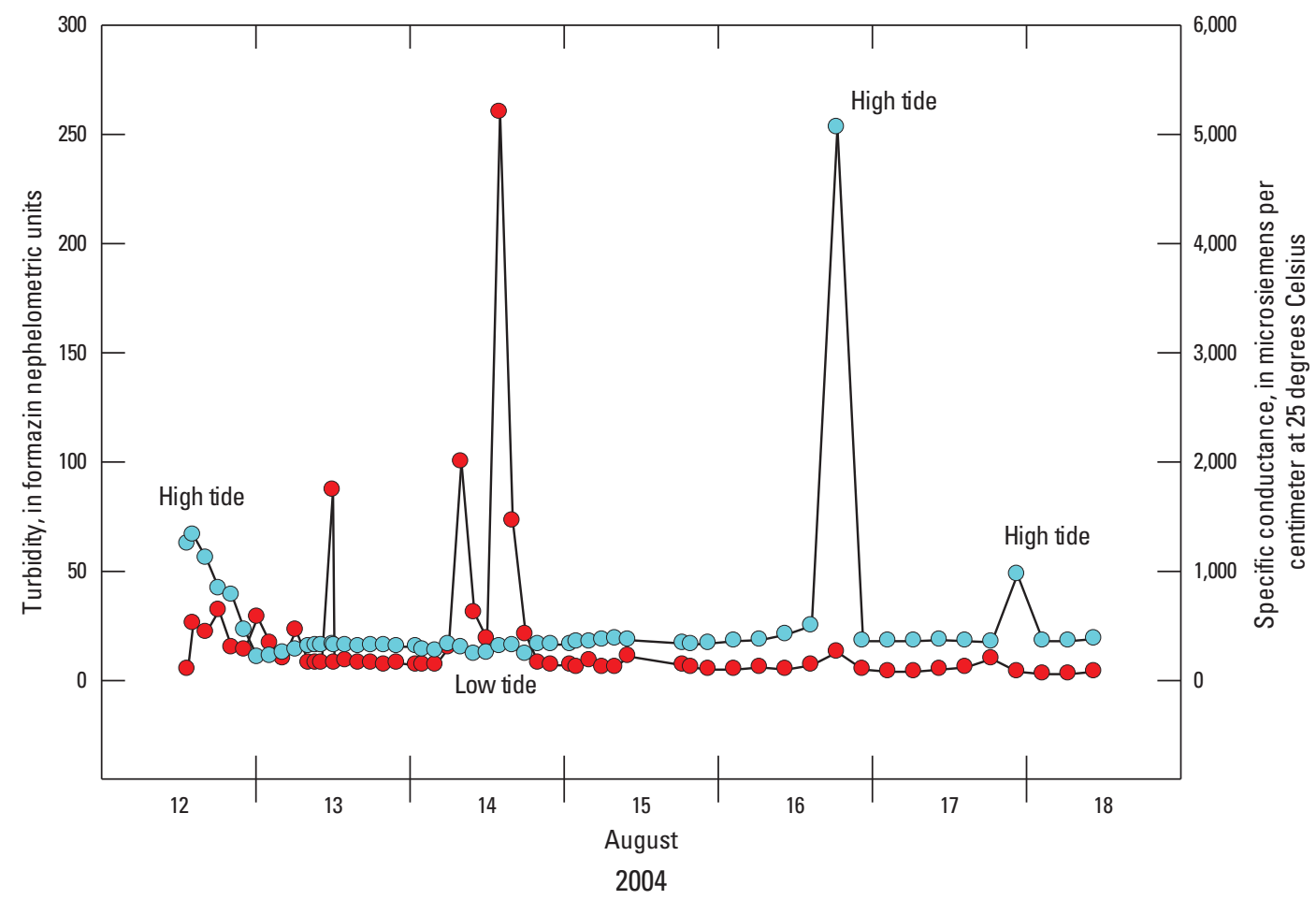

Figure 24. Turbidity and specific conductance concentration, August 12-18, 2004, 5th Avenue crosswalk water-quality data collection station near Surfside Beach, South Carolina. The relative position of the tide is shown. 


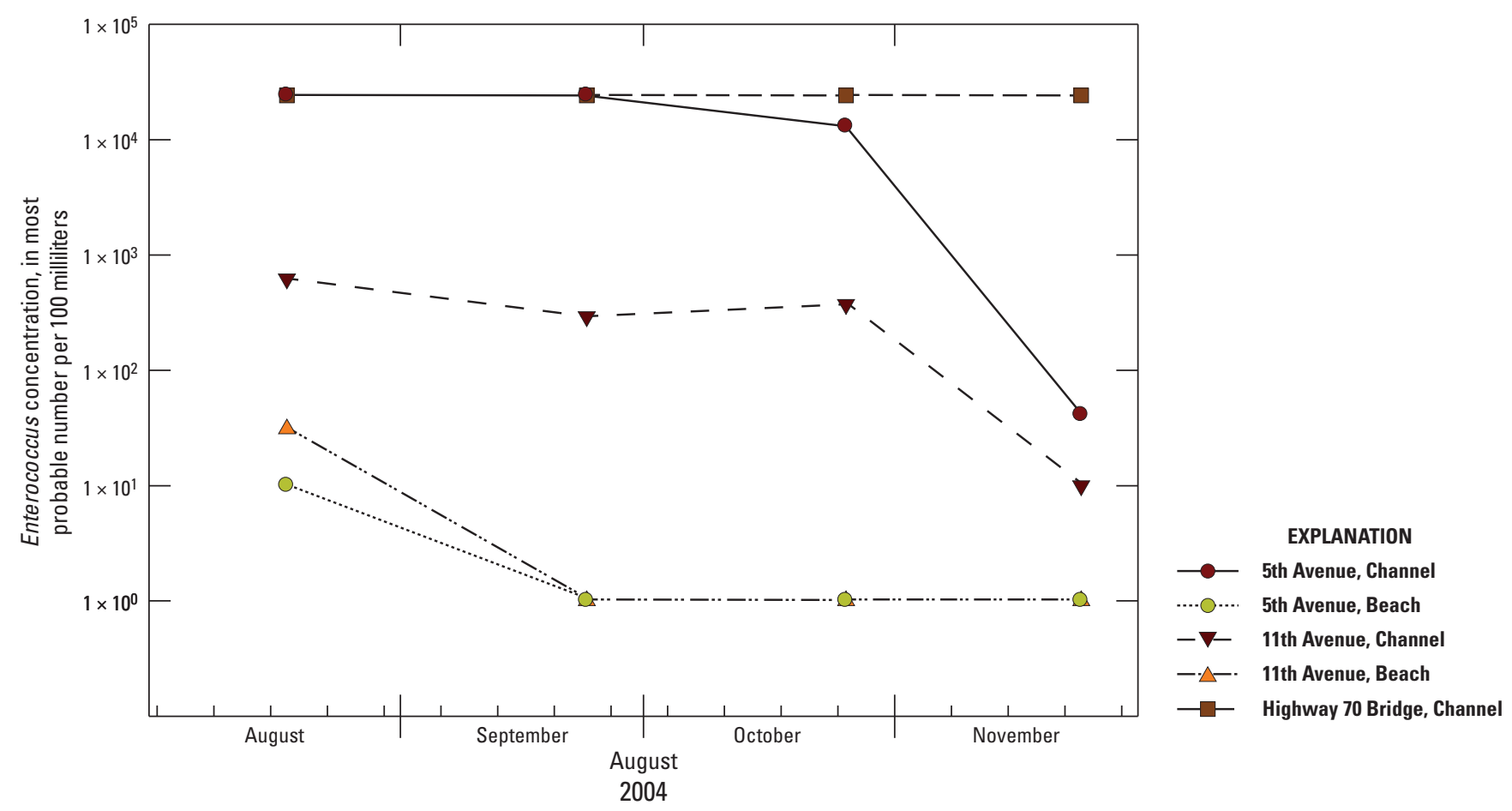

Figure 25. Enterococcus concentration measured in bed-sediment samples collected from the three water-quality data collection stations and incubated over time in static microcosms in the laboratory. The Enterococcus concentrations are log transformed.

Enterococcus concentrations were observed at the beginning of the study for bed sediments collected from the channel at the 5th Avenue crosswalk WQDCS, but decreased slowly over the 4-month study (fig. 25). Bed sediments collected from the delta in Lake Myrtle also showed high Enterococcus concentrations after collection (appendix tables 1-1, 1-2, 1-3). In contrast, the Enterococcus concentrations in bed sediments collected at the 11th Avenue crosswalk WQDCS were initially lower and also slowly decreased. The Enterococcus concentrations in beach sand collected from the surf zone were at detection levels throughout most of the laboratory study.

It is not clear if this persistence of enterococci in bed sediments at the 5th Avenue crosswalk and Highway 707 Bridge WQDCS channels is due to cell viability or cell growth. Other studies have determined that fecal bacteria (such as E. coli, enterococci, and Bacteroides) can survive in beach sand at freshwater lakes in Michigan (Alm and others, 2003), coastal beaches in California (Yamahara and others, 2007), and tidally-affected freshwater marsh soils (Drexler and others, 2014), respectively. These data do indicate, however, that enterococci can exist in these channel bed-sediment environments outside of a host for a long time at these sites. These results challenge the conventional use of Enterococcus concentrations as an indicator of the recent (within 1 day) introduction of fecal-related material and the associated acute risk to other pathogens, which has been discussed as a component of previous investigations (Journey and Conlon, 2013).

\section{Summary}

An investigation was completed between 2003 and 2004 to determine if Enterococcus concentrations in surface water could be assessed using turbidity in the study area of coastal Horry County, South Carolina. The study was designed to assess the relation between Enterococcus concentrations and turbidity, which, unlike Enterococcus concentrations, can be measured continuously by using a multiparameter water-quality sensor and results reported in real time. In 2003, three water-quality data collection stations that included a multiparameter water-quality sensor that measured turbidity were located in three representative surface-water basins in coastal Horry County, South Carolina. A comparison of Enterococcus concentrations in surface-water samples collected simultaneously using both methods indicated a positive relation, although the average percent relative difference between the methods was 46 percent.

During a period of no precipitation in February 2004, no relation between turbidity and Enterococcus concentrations was observed for surface-water samples collected at the water-quality data collection station located in the channel that drains a freshwater swamp. In contrast, during periods of precipitation in March and August 2004 at this location, a positive relation was observed between turbidity and Enterococcus concentrations in surface-water samples; that is, water samples characterized by higher turbidity also contained higher Enterococcus concentrations. At the water-quality 
data collection station located in a channel that drains to the surf zone of the Atlantic Ocean, no relation was observed between turbidity and Enterococcus concentrations during periods of either no precipitation (July 2004) or precipitation (August 2004). At this location, the turbidity was inversely related to relative tide height, high turbidity was observed during low tide when freshwater flowed seaward, and low turbidity was observed during high tide when saline seawater flowed landward.

The positive relation observed between turbidity and Enterococcus concentrations in surface water at the waterquality data collection station located in the channel that drains a freshwater swamp may be attributed to bacterial survival in the abundant channel bed sediments that characterized this more naturalized area. Surface-water bed sediments collected near each water-quality data collection station and the surf zone and incubated in static microcosms in the laboratory indicated that Enterococcus concentrations continued to persist in bed sediments collected from the channel that drains the swamp even after almost 4 months of incubation. Conversely, Enterococci were not observed to persist in bed sediments collected from the beach and characterized by high specific conductance. Although it is currently (2016) unknown whether this persistence of Enterococci demonstrates growth or viability, the data indicate that Enterococci can exist in channel bed-sediment environments outside of a host for a long time. This observation confirms previous reports that challenge the use of Enterococcus concentrations as an indicator of the recent introduction of fecal-related material and the associated acute risk to other pathogens.

\section{References Cited}

Alm, E.W., Burke, Janice, and Spain, Anne, 2003, Fecal indicator bacteria are abundant in wet sand at freshwater beaches: Water Research, v. 37, no. 16, p. 3978-3982. [Also available at http://dx.doi.org/10.1016/S00431354(03)00301-4.]

Auer, M.T., and Niehaus, S.L, 1993, Modeling fecal coliform bacteria-I. field and laboratory determination of loss kinetics: Water Research, v. 27, no. 4, p. 693-701. [Also available at http://dx.doi.org/10.1016/0043-1354(93)90179-L.]

American Public Health Association, 1992, Standard methods for the examination of water and wastewater (18th ed.): Washington, American Public Health Association, 1100 p.

Baldwin, A.K., Robertson, D.M., Saad, D.A., and Magruder, Christopher, 2013, Refinement of regression models to estimate real-time concentrations of contaminants in the Menomonee River drainage basin, southeast Wisconsin, 2008-11: U.S. Geological Survey Scientific Investigations Report 2013-5174, 113 p., 7 appendixes. [Also available at http://pubs.usgs.gov/sir/2013/5174/.]
Brady, A.M.G., Bushon, R.N., and Plona, M.B., 2009, Predicting recreational water quality using turbidity in the Cuyahoga River, Cuyahoga Valley National Park, Ohio, 2004-7: U.S. Geological Survey Scientific Investigations Report 2009-5192, 16 p. [Also available at http://pubs.usgs.gov/sir/2009/5192/.]

Buckwalter, T.F., Zimmerman, T.M., and Fulton, J.W., 2006, Fecal-indicator bacteria in the Allegheny, Monongahela, and Ohio Rivers and selected tributaries, Allegheny County, Pennsylvania, 2001-2005: U.S. Geological Survey Scientific Investigations Report 2006-5216, 27 p. [Also available at http://pubs.usgs.gov/sir/2006/5216/.]

Cabelli, V.J., 1977, Indicators of recreational water quality, in Hoadley, A.W., and Dutka, B.J., eds., Bacterial indicators/ health hazards associated with water: Philadelphia, Pa., American Society for Testing and Materials, Special Technical Publication 635, p. 222-238.

Cabelli, V.J., 1983, Health effects criteria for marine recreational waters: Research Triangle Park, N.C., U.S. Environmental Protection Agency, Health Effects Research Laboratory, EPA-600/1-80-031. [Also available at http://nepis.epa.gov/Exe/ZyPDF.cgi/300000E1. PDF?Dockey=300000E1.PDF.]

Cabelli, V.J., Dufour, A.P., McCabe, L.J., and Levin, M.A., 1982, Swimming associated gastroenteritis and water quality: American Journal of Epidemiology, v. 115, no. 4, p. 606-616.

Christensen, V.G., 2001, Characterization of surface-water quality based on real-time monitoring and regression analysis, Quivira National Wildlife Refuge, South Central Kansas, December 1998 through June 2001: U.S. Geological Survey Water-Resources Investigations Report 01-4248, 28 p. [Also available at http://ks.water.usgs.gov/pubs/ reports/wrir.01-4248.html.]

Christensen, V.G., Jian, Xiaodong, and Zeigler, A.C., 2000, Regression analysis and real-time water-quality monitoring to estimate constituent concentrations, loads, and yields in the Little Arkansas River, South Central Kansas, 1995-99: U.S. Geological Survey Water-Resources Investigations Report 00-4126, 35 p. [Also available at http://ks.water. usgs.gov/pubs/reports/wrir.00-4126.html.]

Davis \& Floyd, Inc., 2002, Storm water outfall study, Horry County Beaches, for Horry County, South Carolina: Greenwood, S.C., Davis \& Floyd, Inc., Environmental Division, Job No. 11298.00 [variously paged]. [Also available at http://stormwater.horrycounty.org/Portals/21/Documents/ Studies/DAVIS_FLOYD_FINAL\%20REPORT.pdf.]

Drexler, J.Z., Johnson, H.E., Duris, Joseph, and Krauss, K.W., 2014, Marsh soils as potential sinks for Bacteroides fecal indicator bacteria, Waccamaw National Wildlife Refuge, Georgetown, SC, USA: Water Air Soil Pollution, v. 225, no. 1861,7 p. [Also available at http://dx.doi.org/10.1007/ s11270-013-1861-1.] 
Dufour, A.P., 1984, Health effects criteria for fresh recreational waters: Research Triangle Park, N.C., U.S. Environmental Protection Agency, Health Effects Research Laboratory, EPA-600/1-84-004, accessed January 31, 2012, at http:// www.epa.gov/microbes/documents/frc.pdf.

Eidson, J.P., Lacy, C.M., Nance, Luke, Hansen, W.F., Lowery, M.A., and Hurley, N.M., Jr., 2005, Development of a 10- and 12-digit hydrologic unit code numbering system for South Carolina, 2005: U.S. Department of Agriculture, Natural Resources Conservation Service, 38 p., 1 pl. [Also available at http://www.nrcs.usda.gov/Internet/FSE_DOCUMENTS/nrcs142p2_015367.pdf.]

Francy, D.S., Gifford, A.M., and Darner, R.A., 2002, Escherichia coli at Ohio bathing beaches-distribution, sources, wastewater indicators, and predictive modeling: U.S. Geological Survey Water-Resources Investigations Report 02-4285, 47 p. [Also available at http://oh.water.usgs.gov/ reports/Abstracts/wrir02-4285.html.]

Francy, D.S., Brady, A.M.G., Carvin, R.B., Corsi, S.R., Fuller, L.M., Harrison, J.H., Hayhurst, B.A., Lant, J., Nevers, M.B., Terrio, P.J., and Zimmerman, T.M., 2013, Developing and implementing predictive models for estimating recreational water quality at Great Lakes beaches: U.S. Geological Survey Scientific Investigations Report 2013-5166, 68 p. [Also available at http://dx.doi.org/10.3133/ sir20135166/.]

Fulton, J.W., and Buckwalter, T.F., 2004, Fecal-Indicator Bacteria in the Allegheny, Monongahela, and Ohio Rivers, near Pittsburgh, Pennsylvania, July-September 2001: U.S. Geological Survey Scientific Investigations Report 2004-5009, 39 p. [Also available at http://pubs.usgs. gov/sir/2004/5009/.]

Guimaraes, W.B., 1995, Water quality in the Withers Swash basin, with emphasis on enteric bacteria, Myrtle Beach, South Carolina, 1991-93: U.S. Geological Survey WaterResources Investigations Report 95-4125, 102 p. [Also available at https://pubs.er.usgs.gov/publication/wri954125.]

Haack, S.K., Fogarty, L.R., and Wright, Christopher, 2003, Escherichia coli and enterococci at beaches in the Grand Traverse Bay, Lake Michigan-Sources, characteristics, and environmental pathways: Environmental Science and Technology, v. 37, no. 15, p. 3275-3282. [Also available at http://dx.doi.org/10.1021/es021062n.]

Holtschlag, D.J., Shively, Dawn, Whitman, R.L., Haack, S.K., and Fogarty, L.R., 2008, Environmental factors and flow paths related to Escherichia coli concentrations at two beaches on Lake St. Clair, Michigan, 2002-2005: U.S. Geological Survey Scientific Investigations Report 2008-5028, 38 p. [Also available at http://pubs.usgs.gov/

$\operatorname{sir} / 2008 / 5028 /$.
Hyer, K.E., and Moyer, D.L., 2003, Patterns and sources of fecal coliform bacteria in three streams in Virginia, 1999-2000: U.S. Geological Survey Water-Resources Investigations Report 03-4115, 76 p. [Also available at http://pubs.usgs.gov/wri/wri034115/.]

Journey, C.A., and Conlon, K.J., 2013, Characterization of stormwater at selected South Carolina Department of Transportation maintenance yard and section shed facilities in Ballentine, Conway, and North Charleston, South Carolina, 2010-2012: U.S. Geological Survey Scientific Investigations Report 2013-5175, 82 p., http://dx.doi.org/10.3133/ sir20135175.

Juckem, P.F., Corsi, S.R., McDermott, Colleen, Kleinheinz, Gregory, Fogarty, L.R., Haack, S.K., and Johnson, H.E., 2013, Evaluation of potential sources and transport mechanisms of fecal indicator bacteria to beach water, Murphy Park Beach, Door County, Wisconsin: U.S. Geological Survey Scientific Investigations Report 2012-5190, 29 p. [Also available at http://pubs.usgs.gov/sir/2012/5190/.]

Milligan, J.D., 1988, Evaluation of sample holding time extension for Escherichia coli and enterococci measurements: Chemosphere, v. 17, no. 6, p. 1241-1245. [Also available at http://dx.doi.org/10.1016/0045-6535(88)90191-9.]

Natural Resources Defense Council, 2002, Testing the waters 2002 - A guide to water-quality at vacation beaches: Natural Resources Defense Council, accessed March 4, 2003, at http://www.nrdc.org/water/oceans.

Natural Resources Defense Council, 2014, Testing the waters 2014 - A guide to water-quality at vacation beaches: Natural Resources Defense Council, accessed April 1, 2015, at http://www.nrdc.org/water/oceans/ttw/.

Rasmussen, P.P., and Ziegler, A.C., 2003, Comparison and continuous estimates of fecal coliform and Escherichia Coli bacteria in selected Kansas streams, May 1999 through April 2002: U.S. Geological Survey Water-Resources Investigations Report 03-4056, 80 p. [Also available at http:// ks.water.usgs.gov/pubs/abstracts/wrir.abstract.03-4056. html.]

Rasmussen, T.J., and Gatotho, Jackline, 2014, Water-quality variability and constituent transport and processes in streams of Johnson County, Kansas, using continuous monitoring and regression models, 2003-11: U.S. Geological Survey Scientific Investigations Report 2013-5221, p. 53. [Also available at http://dx.doi.org/10.3133/sir20135221.]

Rasmussen, T.J., Lee, C.J., and Ziegler, A.C., 2008, Estimation of constituent concentrations, loads, and yields in streams of Johnson County, northeast Kansas, using continuous waterquality monitoring and regression models, October 2002 through December 2006: U.S. Geological Survey Scientific Investigations Report 2008-5014, 103 p. [Also available at http://pubs.usgs.gov/sir/2008/5014/.] 
Rasmussen, T.J., Ziegler, A.C., and Rasmussen, P.P., 2005, Estimation of constituent concentrations, densities, loads, and yields in Lower Kansas River, northeast Kansas, using regression models and continuous water-quality monitoring, January 2000 through December 2003: U.S. Geological Survey Scientific Investigations Report 2005-5165, 117 p. [Also available at http://pubs.usgs.gov/sir/2005/5165/.]

Schaepe, N.J., Soenksen, P.J., and Rus, D.L., 2014, Relations of water-quality constituent concentrations to surrogate measurements in the lower Platte River corridor, Nebraska, 2007 through 2011: U.S. Geological Survey Open-File Report 2014-1149, 16 p. [Also available at http://dx.doi. org/10.3133/ofr20141149.]

Schillinger, J.E., and Gannon, J.J., 1982, Coliform attachment to suspended particles in stormwater: Ann Arbor, Mich., The University of Michigan, $42 \mathrm{p}$.

Tukey, J.W., 1977, Exploratory data analysis: London, Addison-Wesley Publishing Company, 688 p.

U.S. Environmental Protection Agency, 1986, Ambient water quality criteria for bacteria-1986: Washington, U.S. Environmental Protection Agency, Office of Water, Regulations and Standards Criteria and Standards Division, EPA 440/5-84-002, 18 p. [Also available at https://www.regulations.gov/\#! documentDetail;D=EPAHQ-OW-2007-0808-0001.]

U.S. Environmental Protection Agency, 1993, Methods for the determination of inorganic substances in environmental samples: Cincinnati, Ohio, U.S. Environmental Protection Agency, Office of Research and Development, Environmental Monitoring Systems Laboratory, EPA/600/R-93/100, 178 p. [Also available at http://nepis.epa.gov/Exe/ZyPDF. cgi/30002U3P.PDF?Dockey=30002U3P.PDF.]
U.S. Environmental Protection Agency, 2007, 40 CFR Parts 136 and 503-Guidelines establishing test procedures for the analysis of pollutants; analytical methods for the biological pollutants in wastewater and sewage sludge final rule: EPA-HQ-QW-2004-0014, U.S. Federal Register, v. 72, no. 57, p. 14220-14233. [Also available at https://www.gpo.gov/fdsys/pkg/FR-2007-03-26/pdf/ 07-1455.pdf.]

U.S. Environmental Protection Agency, 2012, Recreational water quality criteria: U.S. Environmental Protection Agency, Office of Water, 820-F-12-058, 63 p., accessed April 24, 2015, at http://water.epa.gov/scitech/ swguidance/standards/criteria/health/recreation/upload/ RWQC2012.pdf.

U.S. Geological Survey, variously dated, National field manual for the collection of water-quality data: U.S. Geological Survey Techniques of Water-Resources Investigations, book, 9, chap. A1-A9, accessed June 12, 2013, at http://pubs.water.usgs.gov/twri9A/.

Yamahara, K.M., Layton, B.A., Santoro, A.E., and Boehm, A.B., 2007, Beach sands along the California coast are diffuse sources of fecal bacteria to coastal waters: Environmental Science \& Technology, v. 41, no. 13, p. 4515-4521. [Also available at http://dx.doi.org/10.1021/es062822n.]

Zimmerman, T.M., 2006, Monitoring and modeling to predict Escherichia coli at Presque Isle Beach 2, City of Erie, Erie County, Pennsylvania: U.S. Geological Survey Scientific Investigation Report 2006-5159, 15 p. [Also available at http://pubs.usgs.gov/sir/2006/5159/.] 

Manuscript approved February 10, 2016

Prepared by the Rolla, Lafayette, and Reston Publishing Service Centers

Rebekah Davis and Michael Deacon, Editors

Kimberly Swidarski, Layout and Illustrations

For more information about this publication, contact:

Director

U.S. Geological Survey

South Atlantic Water Science Center

1770 Corporate Drive

Suite 500

Norcross, GA 30093

Phone: (678) 924-6700

or visit our Web site at

https://www2.usgs.gov/water/southatlantic/ 
(D)

흠

I⿸丆口

.

罸

悉

m

홍

กิ๊

8

(9)

:

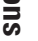

言

言

ह.

疋

言

言

言

尹ౌ

然

言

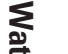

帝

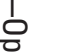

竞

ग

응

$\widetilde{O}$

항

ISSN 2331-1258 (online) 